\title{
Polyphenols, glucosinolates, dietary fibre and colon cancer: Understanding the potential of specific types of fruit and vegetables to reduce bowel cancer progression
}

\author{
Noura Eid, Gemma Walton, Adele Costabile, Gunter G.C. Kuhnle and Jeremy P.E. Spencer* \\ School of Chemistry, Food and Pharmacy, Department of Food and Nutritional Sciences, University of Reading, \\ Reading, UK
}

\begin{abstract}
Colorectal cancer is the third most prevalent cancer worldwide and the most common diet-related cancer, influenced by diets rich in red meat, low in plant foods and high in saturated fats. Observational studies have shown that fruit and vegetable intake may reduce colorectal cancer risks, although the precise bioactive components remain unclear. This review will outline the evidence for the role of polyphenols, glucosinolates and fibres against cancer progression in the gastrointestinal tract. Those bioactive compounds are considered protective agents against colon cancer, with evidence taken from epidemiological, human clinical, animal and in vitro studies. Various mechanisms of action have been postulated, such as the potential of polyphenols and glucosinolates to inhibit cancer cell growth and the actions of insoluble fibres as prebiotics and the evidence for these actions are detailed within. In addition, recent evidence suggests that polyphenols also have the potential to shift the gut ecology in a beneficial manner. Such actions of both fibre and polyphenols in the gastrointestinal tract and through interaction with gut epithelial cells may act in an additive manner to help explain why certain fruits and vegetables, but not all, act to differing extents to inhibit cancer incidence and progression. Indeed, a focus on the individual actions of such fruit and vegetable components, in particular polyphenols, glucosinolates and fibres is necessary to help explain which components are active in reducing gastrointestinal cancer risk.
\end{abstract}

Keywords: Polyphenol, glucosinolate, fibre, fruit and vegetables, cancer, gut microbiota

\section{Introduction}

Cancer is one of the most widespread chronic diseases and one that is increasing in incidence in developing countries as a result of poor lifestyle choices [1-3]. Cancer is characterised by uncontrolled cellular growth that occurs as a consequence of alterations to, or the damage of genetic material [4] and it has been predicted that around 30 to $40 \%$ of various cancers may be modifiable by diet [5] in particular colorectal (CRC) [6, 7]. CRC is the 3rd most prevalent

*Corresponding author: Jeremy P.E. Spencer, School of Chemistry, Food and Pharmacy, Department of Food and Nutritional Sciences, University of Reading, Reading RG6 6AP, UK. E-mail: j.p.e.spencer@reading.ac.uk. form of cancer (after lung and breast) and, as such, represents a major public health risk [3]. Colon carcinogenesis develops through a "multi-step" process, which starts with a period of abnormal epithelial proliferation, called 'hyperplasia', followed by a period of epithelial 'dysplasia' during which abnormal cell development occurs [8]. The abnormal colonocytes that result may lead to the formation of a "polyp" or "adenoma" at diverse sites along the surface of the colon and whilst these pedunculated, or sometimes sessile structures, are largely benign and asymptomatic, they may transform, over time, into malignant polyps marking the later stages of cancer development [9].

Various factors are associated with colon cancer development $[10,11]$, including genetic susceptibility 
[12], gender [13], age [14, 15], socioeconomic status [16], race [17], excessive alcohol intake [18], smoking [19] and diet [6, 7, 20-25]. The sensitivity of the GI tract to diet in relation to cancer risk derives predominantly from the fact that the gut epithelium encounters, and interacts with, a vast array of nutrient and non-nutrient compounds, beneficial and detrimental, introduced through the diet. Dietary habits that correlate with the promotion of carcinogenesis include the intake of high amounts of haem iron present in processed and red meat [26-28], high fat consumption [29], and a low intake of plant-derived foods [30-32]. Amongst these, plant foods, which include, fruits and vegetables have also received much interest with regards to their anti-cancer potential [24, 32-38] and studies have identified that both fibres [30, 39] and phytochemicals [40-42] act as mediating protective components. This review will consider the latest evidence for the actions of fruit and vegetable intake and their constituent phytochemicals and fibres on cancer incidence and/or carcinogenesis in the GI tract. We will give an overview of the mechanisms by which constituent phytochemicals and fibres act to exert such beneficial activity, derived through observational data, animal models and in vitro work.

\subsection{Diet and colorectal cancer}

Colorectal cancer is the archetypal example of a diet-related cancer [3, 43, 44]. The classic 'western diet', rich in red meat, low in plant foods and high in saturated fat, is believed to play a major role in GI health and in the development of GI tract cancer [43]. In support of this, the adoption of a more 'Western diet' by Japanese migrants to the US and the UK has resulted in an increased incidence of CRC in this population [44]. Several hypotheses have been suggested to explain the association between meat consumption and CRC [26-28], including the high temperature formation of heterocyclic amines [27, 45], although this does not sufficiently explain the differences observed between red and white meat. An alternative hypothesis is the level of free [44] or haem bound iron, which itself genotoxic [46], but can also promote the formation of endogenous nitroso compounds that can result in the formation of mutagenic DNA adducts [47]. High meat consumption also displaces low-calorie dense plant foods, which may impact on cancer development in two ways. Firstly, red meat consumption will contribute to saturated fat intake, a factor known to increase CRC risk through the actions of fatty acids and secondary bile acids on the colonic mucosa [29]. Secondly, high red meat intake will potentially displace the intake of less calorie dense, phytochemicals and fibre containing plant foods, which have been postulated to possess cancer protective properties against epithelial cancer development in human [48, 49], animal [50, 51] and cell studies [52, 53]. Despite such data, the effects of plant foods on cancer development may be confounded by other dietary and lifestyle factors, with their intake closely associated with higher physical activity, higher mineral and vitamin intake, lower alcohol consumption, abstinence from cigarette smoking [16, 54-56], and human health factors, which include obesity [16, 57, 58] and aging [59-61].

There is an increasing interest in the role the gut microbiota play in modifying CRC risk [11]. The human gut harbours large numbers of bacterial species, each with unique metabolic capabilities $[62,63]$ and modification of these by non-digestible carbohydrates and fibres has been suggested to reduce CRC development indirectly [62, 64, 65]. Complex plant-derived polysaccharides that escape digestion in the upper gut, undergo saccharolytic metabolism in the large intestine, liberating short-chain fatty acids [65] and selectively affect the growth of the colonic microbiota, such as, bifidobacteria and lactobacilli that may favourably influence CRC risks, by the production of its metabolites [66], that were found to exert various anti-cancer effects [67]. Thus, research has been directed towards the consumption of plant foods, in particular fruit and vegetable intake, to reduce risks of CRC, however observational studies remain inconclusive (Table 1).

\subsection{Fruit and vegetable intake and colon cancer}

Fruit and vegetable consumption makes up an important part of the human diet and such foods deliver varying amounts of phytochemicals and fibre. Many fruits and vegetables are rich in an array of potentially bioactive components, including fibre [68], vitamin C [69], vitamin E [70], selenium [71], carotenoids [72], glucosinolates [73], and polyphenols (including phenolic acids, hydroxycinnamates and flavonoids) [41, 74-81], which have been linked with chemopreventive and anti-carcinogenic actions [82-84]. In 1997, the World Cancer Research Fund (WCRF) classified the evidence for a protective effect of dietary fibres in fruits and vegetables for different types of cancer, 
Table 1

Diet \& colorectal cancer

\begin{tabular}{|c|c|c|c|}
\hline Trial & Duration & Type of food & Main results \\
\hline $\begin{array}{l}\text { Women from Nurses' Health Study } \\
\text { and men from the Health } \\
\text { Professionals Follow-Up } \\
\text { Study [94] }\end{array}$ & $\begin{array}{l}10 \text { year follow up for } \\
\text { females and } 4 \text { years } \\
\text { follow up for males }\end{array}$ & Fruits and vegetables & $\begin{array}{l}\text { No association with reducing risks of } \\
\text { colorectal cancers }\end{array}$ \\
\hline $\begin{array}{l}\text { Nested case-control study from the } \\
\text { Alpha-Tocopherol Beta-Carotene } \\
\text { Study cohort of male smokers [56] }\end{array}$ & 5 to 8 years follow up & $\begin{array}{l}\text { The main source of folate, } \\
\text { was mostly green leafy } \\
\text { vegetables }\end{array}$ & $\begin{array}{l}\text { No association was observed between } \\
\text { vegetable rich in folate and colorectal } \\
\text { cancers }\end{array}$ \\
\hline A case-control study [55] & 3 years duration & Smoking and alcohol & $\begin{array}{l}\text { Alcohol and smoking was associated with } \\
\text { increasing the risks of colorectal cancer }\end{array}$ \\
\hline The Adventists' Health Study [243] & 6 years follow up & $\begin{array}{l}\text { Salad and green } \\
\text { vegetables }\end{array}$ & $\begin{array}{l}\text { An inverse association between "salad" and } \\
\text { "green vegetables" with colorectal cancer } \\
\text { was seen }\end{array}$ \\
\hline $\begin{array}{l}\text { In the European Prospective } \\
\text { Investigation into Cancer and } \\
\text { Nutrition (EPIC), } 2009 \text { [32] }\end{array}$ & 8 years follow up & Fruits and vegetables & An inverse association was seen \\
\hline $\begin{array}{l}\text { Cohort prospective study in Los } \\
\text { Angeles, California [33] }\end{array}$ & 8 years follow up & $\begin{array}{l}\text { Fruits and vegetables, and } \\
\text { fruits alone }\end{array}$ & An inverse association with colon cancer \\
\hline Cancer prevention study II [34] & 6 years follow up & Vegetables and grains & $\begin{array}{l}\text { An inverse association was seen with } \\
\text { vegetables and grains }\end{array}$ \\
\hline $\begin{array}{l}\text { The European Prospective } \\
\text { Investigation into Cancer and } \\
\text { Nutrition (EPIC-Oxford) [235] }\end{array}$ & 6 years follow up & Vegetarians & \\
\hline The multiethnic Cohort study [244] & 3 years follow up & $\begin{array}{l}\text { Fruits, vegetable and } \\
\text { grains }\end{array}$ & $\begin{array}{l}\text { Association regarding fruits and colon } \\
\text { cancer risk reduction was seen in men only }\end{array}$ \\
\hline $\begin{array}{l}\text { A prospective investigation on } \\
\text { vegetarians and non vegetarians in } \\
\text { the UK [245] }\end{array}$ & 17 years follow up & $\begin{array}{l}\text { Vegetarians and } \\
\text { non-vegetarians }\end{array}$ & $\begin{array}{l}\text { Vegetarians had reduced risks of colorectal } \\
\text { cancers. It was also seen with fruits } \\
\text { consumption, but not after adjusting } \\
\text { alcohol and smoking }\end{array}$ \\
\hline $\begin{array}{l}\text { Population-based prospective } \\
\text { mammography study of Swedish } \\
\text { women [24] }\end{array}$ & 9.6 years follow up & Fruits and vegetables & $\begin{array}{l}\text { An inverse association with colon cancer and } \\
\mathrm{CRC} \text {, but not with rectal cancer whereas } \\
\text { the association was much stronger with } \\
\text { fruits, in particularly to rectal cancers. }\end{array}$ \\
\hline $\begin{array}{l}\text { The Western Australian Bowel } \\
\text { Health Study [200] }\end{array}$ & 2 years follow up & $\begin{array}{l}\text { Fruits and vegetables; } \\
\text { vegetable intake; fruits } \\
\text { intakes }\end{array}$ & $\begin{array}{l}\text { With regards to the proximal colon cancer, } \\
\text { no association was observed, whereas } \\
\text { distal colon cancer was reduced with apple } \\
\text { and yellow vegetable intakes }\end{array}$ \\
\hline $\begin{array}{l}\text { Pooling Project of Prospective } \\
\text { Studies of Diet and Cancer [246] }\end{array}$ & 6 to 20 years & Fruits and vegetables & $\begin{array}{l}\text { Reductions in distal colon cancer risks was } \\
\text { seen with in comparison with other sites }\end{array}$ \\
\hline
\end{tabular}

including CRC, as "convincing", whereas in 2007, this was downgraded to "probable" [85]. Furthermore, global cancer statistics appear to indicate that fruit and vegetable consumption could reduce the incidence of disease by between 50 to $80 \%$ [3,86, 87], with several cohort and case-control studies indicating a potential reduction in CRC incidence [24, 32-38]. The consumption of fruits and vegetables is advised by the World Health Organization [88], the National Cancer Institute [89], the World Cancer Research Fund 
(WCRF) [90] and the USDA (U.S. Department of Human Services, 2005) to be 3 servings (Austria), 5 servings (United Kingdom) or 9 servings (Greece), daily [91].

However, in 2012, the EPIC consortium indicated a strong relationship between the consumption of foods rich in fibre and phytochemicals, such as fruits, vegetables and cereals, and a reduction in the risk of CRC in non-smokers [92] and highly physical active participants [93]. In addition, other studies have failed to show such a relationship between fruit and vegetable consumption and CRC incidence [56, 94, 95]. This controversy in the literature is likely to reside in the fact that all fruits and vegetables are not equivalent in their ability to exert anti-cancer effects in humans, largely due to their differing content of both phytochemicals and/or fibre. As such, observational data calculated using general fruit and vegetable intake would be expected to yield only a small protective effect, as a majority of 'inactive' fruits and vegetables (with respect to cancer prevention) would 'dilute' the efficacy of the more active ones. Indeed, in studies concentrating on more specific fruit and vegetable intake, such as that of Brassica vegetables (leafy green vegetables, brussels sprouts, cabbage, and string beans), data have been more promising with regards to anti-cancer effects [96], probably due to their fibre, polyphenol and isothiocyanates content $[97,98]$. As such, the population level approach to advising the intake of 5 portions of unspecified fruits and vegetable to prevent cancer is likely flawed. Rather, using evidence from intervention studies and well designed in vivo and in vitro investigations, one should strive to encourage the intake of 5 portions of the most effective cancer preventative fruits and vegetables, most likely those containing the highest levels of polyphenols and/or fibre. As previous epidemiological data does not take account of this, it is likely that previous calculations of the potency of fruits and vegetables to prevent CRC risk are underestimated.

As suggested above, the benefits of fruit and vegetable consumption against CRC development remains unclear, especially with regards to the following: 1) Are all fruits and vegetables equal in inducing cancer protection, and if not then which are the most potent; 2 ) what are the precise causal agents within fruits and vegetables that mediate cancer benefits, which exert the most powerful effects and via what mechanisms; 3) are direct interactions with the GI tract epithelium necessary for anti-cancer actions, or can individual components act indirectly via modulation of the gut microbiota. The remaining part of this review will strive to shed light on these questions and will strive to determine whether a broad, non-specific approach to fruit and vegetable intake at the population level is the most effective strategy for preventing CRC, or whether we should be attempting to target the increased intake of the most effective fruits and vegetables to effectively manage cancer prevention by diet.

\section{Polyphenols and colon cancer prevention}

\subsection{Structure and metabolism}

Phenolic compounds are ubiquitous in the plant kingdom acting as catalysts for photosynthesis [99] and are involved in protecting plants from pathogens, harmful insects' effects and oxidative damage from UV and sunlight [100]. Polyphenols arise in plants from two synthetic pathways "shikimate pathway and the acetate pathway" $[81,101]$ and can be subdivided into several subclasses depending on chemical structures [102], which include, flavonoid and non-flavonoid compounds. Flavonoids, a major class of phenolics in the human diet and can be divided into six major subgroups (Fig. 1) [103]: flavonols (quercetin and kaempferol), found mostly in onions, leeks, broccoli and blueberries; flavones (luteolin and apigenin) found mainly in celery and parsley; flavanones (hesperetin and naringenin) are rich in oranges and grapefruits respectively; isoflavones, found mainly in soya and legumes; flavanols (catechin and proanthocyanidins) are rich in chocolate and tea, and (epigallocatechin and epigallocatechin gallate) are mainly in grapes; proanthocyanidins are rich in peaches, pears, apples and berries; anthocyanins (cyanidin, petunidin, pelargonidin and malvidin). Phenolic acids, on the other hand consist of the benzoic derivatives (hydroxybenzoic acids, gallic acids and tannins) and are found widely in fruits and vegetables as well as nuts, whereas cinnamic derivatives (coumaric, ferulic, sinapic caffeic and chlorogenic acid) are found at great concentrations in coffee [81, 101].

The intake of flavonoids in the human diet has been the subject of much discussion and has been estimated to be $2 \mathrm{mg} /$ daily in the US and UK in 1976 [104], although more recently this has been increased to between 1 to $20 \mathrm{mg} /$ daily [105]. Several factors affect polyphenol intake, including harvest time, UV exposure, ripening time and storage [101, 106, 107], in 


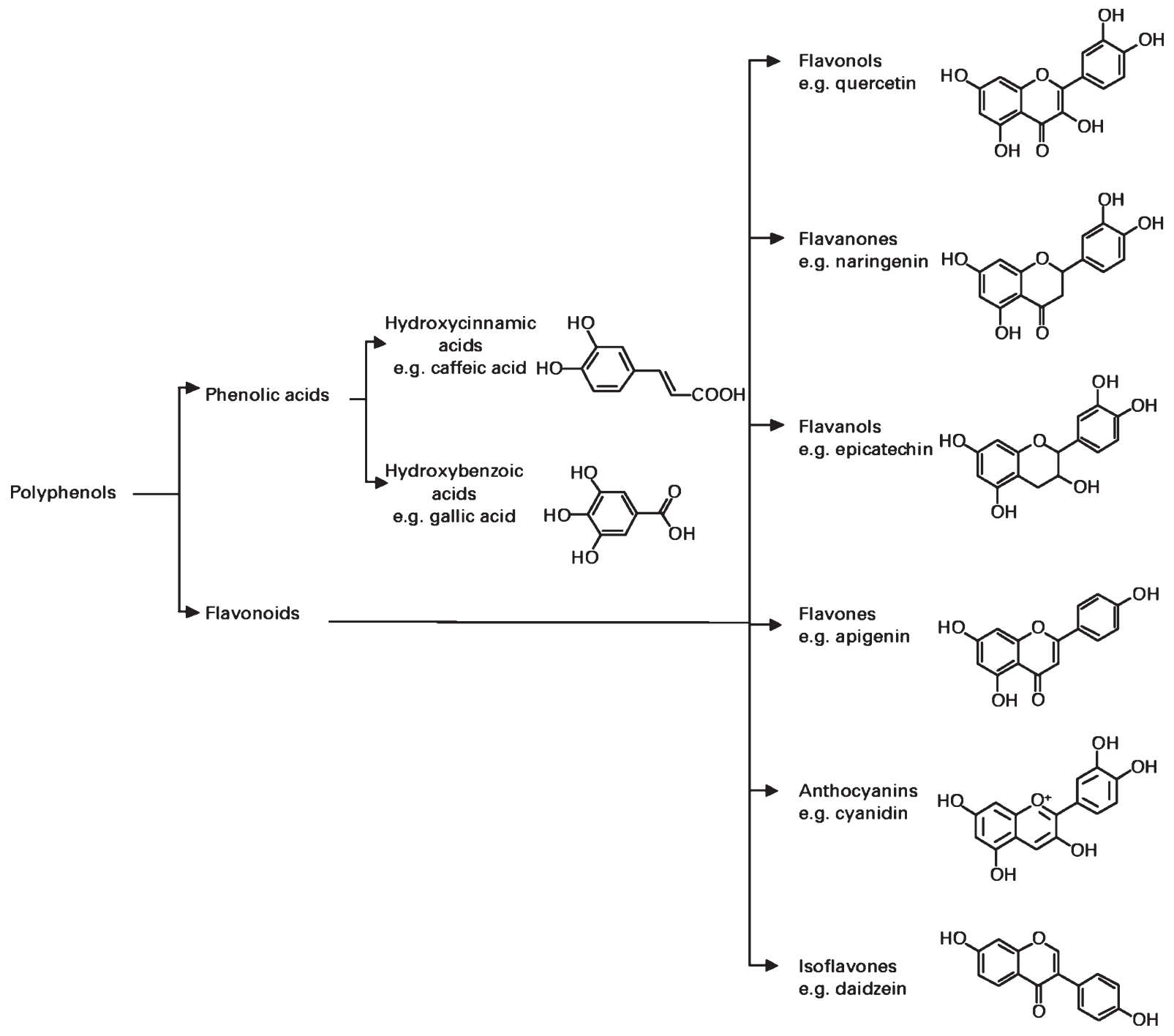

Fig. 1. Polyphenol classification.

addition to the intake of fruits and vegetables a person consumes. With regards to the latter, the complexity associated with assessing population intakes may lead to under-or over-estimates of overall intake [108]. The bioavailability and metabolism of those compounds varies according to its structure [109-111]. The colon is considered the 'primary' site of polyphenol exposure in the human body, as only between 10 and $40 \%$ of polyphenols are absorbed in the small intestine, with the majority passing to the large intestine [112-114] where they may be metabolised by the colonic microbiota [113] leading to potential protective effects [100, $115,116]$.

\subsection{In vivo and in vitro studies}

Observational data have indicated that flavanol [117] isoflavone, flavonol and anthocyanin [118], procyanidin [119] and flavanone [42] intake are associated with an reduction in CRC risk. Furthermore, a significant reduction in cancer recurrence in resected colon cancer patients has been observed after consumption of a mixture of apigenin and epigallocatechin [120]. In vivo studies measuring cancer protection have been conducted in animals [121] and in humans, although data with regards the latter remain inconclusive (Table 2), perhaps dues to low levels of intake 
Table 2

Polyphenols and colorectal cancer

\begin{tabular}{|c|c|c|c|}
\hline Trial & Duration & Type of food & Main results \\
\hline Iowa Women's health study [117] & 12 years follow up & $\begin{array}{l}\text { Catechin from fruits and from } \\
\text { tea }\end{array}$ & $\begin{array}{l}\text { Catechin from fruits was associated with } \\
\text { lowering risks of the upper digestive tract. } \\
\text { Whereas catechin from tea was associated } \\
\text { with lowering risks of rectal cancers }\end{array}$ \\
\hline Italian case-control study [118] & 4 years follow up & $\begin{array}{l}\text { a. Isoflavones, } \\
\text { anthocyanidins, flavones } \\
\text { and flavonols } \\
\text { b. flavan-3-ols, flavanones } \\
\text { and total flavonoids }\end{array}$ & $\begin{array}{l}\text { With a) there was a significant correlation } \\
\text { with reducing colon cancer, whereas with } \\
\text { b) there was not }\end{array}$ \\
\hline $\begin{array}{l}\text { A national prospective case-control } \\
\text { study in Scotland [119] }\end{array}$ & $\begin{array}{l}1 \text { year before } \\
\text { diagnosis }\end{array}$ & $\begin{array}{l}\text { Flavonols, quercetin, } \\
\text { catechin, and epicatechin } \\
\text { from fruit and vegetable or } \\
\text { from other flavonoid } \\
\text { sources. }\end{array}$ & $\begin{array}{l}\text { The significant dose-dependent reductions in } \\
\text { colorectal cancer risk that were associated }\end{array}$ \\
\hline $\begin{array}{l}\text { Women from Nurses' Health Study and } \\
\text { men from the Health Professionals } \\
\text { Follow-Up Study [247] }\end{array}$ & 10 years follow up & $\begin{array}{l}\text { Quercetin, Kaempferol } \\
\text { Myricetin from tea, onions, } \\
\text { apples, broccoli and } \\
\text { tomatoes }\end{array}$ & $\begin{array}{l}\text { In this study there was no association } \\
\text { between flavonoid intakes and colorectal } \\
\text { cancers }\end{array}$ \\
\hline $\begin{array}{l}\text { A prospective study on patients with a } \\
\text { history of resected colon cancer and } \\
\text { others with polypectomized patients } \\
\text { [120] }\end{array}$ & 3 to 4 years follow up & $\begin{array}{l}\text { flavonoid mixture }(20 \mathrm{mg} \\
\text { apigenin and } 20 \mathrm{mg} \\
\text { epigallocatechin-gallate } \\
\text { daily) }\end{array}$ & $\begin{array}{l}\text { Patients with resected colon cancer where } \\
\text { treated with flavonoids, and no occurrence } \\
\text { of cancer was seen }\end{array}$ \\
\hline Case-control study [42] & 10 years follow up & $\begin{array}{l}\text { a. Tea flavonoids; flavonol, } \\
\text { procyanidin and flavon-3-ol } \\
\text { b. Non-tea flavonoids; } \\
\text { quercetin } \\
\text { c. Dietary flavonoids; in fruits } \\
\text { and vegetable }\end{array}$ & $\begin{array}{l}\text { The only association with lowering risks of } \\
\text { colon cancer was seen with non-tea } \\
\text { drinkers }\end{array}$ \\
\hline $\begin{array}{l}\text { Study cohort of the Alpha-Tocopherol, } \\
\text { Beta-Carotene Cancer prevention } \\
\text { (ATBC) in Finland [248] }\end{array}$ & 6.1 years follow up & Flavonol and flavones intake & $\begin{array}{l}\text { There was no association with reducing risks } \\
\text { of colon cancer }\end{array}$ \\
\hline $\begin{array}{l}\text { Prospective study from the Women's } \\
\text { health Study [16] }\end{array}$ & 11.5 years follow up & $\begin{array}{l}\text { - Total flavonoids } \\
\text { - Individual flavonols } \\
\text { (quercetin, kaempferol, and } \\
\text { myricetin) and flavones } \\
\text { (apigenin and luteolin) } \\
\text { - Flavonoid-rich foods (tea, } \\
\text { apple, broccoli, onion, and } \\
\text { tofu) }\end{array}$ & $\begin{array}{l}\text { With a), b) and c) there was no association } \\
\text { with reducing risks of colorectal cancers }\end{array}$ \\
\hline $\begin{array}{l}\text { A human trial on patients with } \\
\text { advanced stage of colon cancer [212] }\end{array}$ & $\begin{array}{l}\text { Received every } 14 \\
\text { days for } 4 \text { weeks }\end{array}$ & $\begin{array}{l}\text { Flavopiridol, a synthetic } \\
\text { flavone that inhibits cell } \\
\text { cycle progression }\end{array}$ & $\begin{array}{l}\text { Treatment with Flavopiridol did not show } \\
\text { any changes in the colon cancer } \\
\text { proliferation }\end{array}$ \\
\hline $\begin{array}{l}\text { A human trial on Familial } \\
\text { adenomatous polyposis (FAP) [249] }\end{array}$ & $\begin{array}{l}6 \text { month treatment ( } 3 \\
\text { times per day) }\end{array}$ & Curcumin and quercetin & $\begin{array}{l}\text { Treatments have successfully reduced the } \\
\text { number of adenomas in colon }\end{array}$ \\
\hline $\begin{array}{l}\text { The Colorectal Adenoma Study in } \\
\text { Tokyo (CAST) [250] }\end{array}$ & 1 year duration & Isoflavones & $\begin{array}{l}\text { There was a significant association in } \\
\text { reducing colorectal cancer risks in both } \\
\text { Japanese male and females }\end{array}$ \\
\hline
\end{tabular}


relative to those used in vitro experiments [122]. Human trials with respect to colorectal cancer have predominantly been designed to assess the impact of fruits and vegetables on colon health by assessment of transit time, beneficial bacterial growth and the presence of anti-cancer agents, rather than by assessment if specific cancer endpoints. Unlike those trials assessing cardiovascular risk, where blood pressure, vascular function and LDL cholesterol may be assessed non-evasively, assessment of cancer reduction in the GI tract requires surgical intervention due to a distinct lack of prognostic biomarkers of cancer status. As such, most work in this area has been conducted using animal models, which have been largely positive in terms of detecting significant inhibition of cancer development afforded to ferulic acid, quercetin, resveratrol and anthocyanins [50, 123-129]. However, caution with respect to the dose of polyphenol exposure should be expressed here with some animal trials indicating an increase in tumour lesions rather than decreasing, when polyphenols, such as quercetin were used at high doses [130, 131]. Indeed, in vitro data suggest that specific polyphenols are less cytotoxic than others and dose dependency has been observed with anthocyanins $[132,133]$.

In support of these animal studies, a large number of in vitro studies have indicated that the effects of polyphenol rich extracts and individual polyphenols induce apoptosis of gut epithelial adenocarcinoma cells [52, 122, 134-144], thus suggesting that these compounds may reduce tumour size in the large gut. These data are supported by other studies that indicate many specific apoptotic markers are induced following exposure of colon cancer cells to polyphenols $[138,139,145,146]$. Alternatively, they have been shown to inhibit the proliferation of cancer cells [52], which may be mediated by a number of mechanisms, including their potential to inhibit the cell cycle to interfere with cell signalling $[138,147]$ and down regulate specific MAPK kinase and transcription factors $[10,52,148-150]$. This is significant as several members of the MAPK signalling pathway, including ERK and JNK are involved in cellular apoptosis and proliferation, as well as tumour invasion and metastasis [151]. The inhibitory effects of polyphenols against colon cancer may also be related to their potential to influence inflammatory status [152] observed with cocoa polyphenols, that have inhibited inflammatoryinduced colon cancer in rat models, via modulating pro-inflammatory enzymes, such as, cyclo-oxygenase2 (COX-2) and NO synthase (iNOS) [153].
With regards to epidemiological observations, there is still a lack of evidence to link polyphenols found in specific fruits and vegetables to a reduction in colorectal cancer risk. However, evidence from studies with tea flavanols, onions and apples [119], anthocyanidins [118] and isoflavones in soya [154] have all provided data suggesting that these polyphenolrich foods are effective. In addition, experiments with quercetin and curcumin have been shown to be effective in treating patients suffering from colon cancer [64] and apigenin/epigallocatechin-gallate are effective in those with a history of polypectomized tumours [120], similar to that observed in vitro work [52]. These studies highlight that flavonoids, flavonoid rich foods and/or other polyphenols may act as effective anti-cancer agents to reduce the adenomas and the recurrence of cancer $[64,120]$.

\subsection{Impact on the microbiota}

The specific actions of polyphenols on the gut microbiota have been initially focussed on its metabolites actions [155] their antimicrobial effects towards pathogenic bacteria [156, 157], and their potential to reduce intestinal inflammation [158, 159]. However, more recently, there has been increasing focus on the potential to specifically modify the growth of favourable gut bacteria to achieve 'healthy' gut ecology [64, 115, 160-162]. For example, it has been demonstrated that polyphenols rich foods and polyphenol extracts may exhibit prebiotic effects in human trials (Table 3 ) and in pH-controlled batch culture experiments [155]. The potential to shift the gut ecology and increasing specific bacterial species, such as beneficial bacteria and butyrate-producing microbes might have the potential to reduce colorectal cancer risk [163]. With regards to human studies, high cocoaflavanol intervention ( $494 \mathrm{mg} /$ day) has been shown to induce a significant increase in both bifidobacteria and lactobacilli and a decrease in clostridia species [164]. These data are in agreement with previous in vitro data, which also indicated the ability of flavanols to positively shift the microbiota [155]. Whole grain breakfast cereals have also been shown to induce a positive influence of microbial growth in human volunteers, with ferulic acid postulated to be involved in these effects in addition to fibres [165].

The concept that polyphenols might beneficially modify the microbiota towards a state that is anti- 
Table 3

Polyphenols and the gut microbiota

\begin{tabular}{lccc}
\hline Trial & Duration & Type of food & Main results \\
\hline $\begin{array}{c}\text { A randomized, controlled, double-blind, crossover } \\
\text { intervention study [164] }\end{array}$ & $\begin{array}{c}4 \text { weeks } \\
\text { treatment }\end{array}$ & Cocoa-derived flavanols & $\begin{array}{c}\text { Significant increase in bifidobacteria and } \\
\text { lactobacilli, and a decrease in clostridia }\end{array}$ \\
$\begin{array}{c}\text { A randomized, controlled, double-blind, crossover } \\
\text { intervention study [174] }\end{array}$ & $\begin{array}{c}\text { 6 weeks } \\
\text { treatment }\end{array}$ & Wild blueberry drink & $\begin{array}{c}\text { Significant increase in total Eubacterium and } \\
\text { Bifidobacteria, whereas lactobacilli have } \\
\text { increased by the treatment and the placebo }\end{array}$ \\
$\begin{array}{c}\text { A randomized, controlled, double-blind, crossover } \\
\text { intervention study [65] }\end{array}$ & $\begin{array}{c}4 \text { weeks } \\
\text { treatment }\end{array}$ & Red wine & $\begin{array}{c}\text { Significant increase in bifidobacteria, } \\
\text { enterecocci, prevotella, Bacteroides, } \\
\text { Bacteroides uniformis, and Blautia } \\
\text { coccoides-Eubacterium rectale }\end{array}$ \\
\hline
\end{tabular}

carcinogenic is related to two factors. Firstly, the reduced growth of certain species of E. Coli and some clostridium species will prevent carcinogen production (via bacterial $\beta$-glucuronidase and $\beta$ nitroreductase activity) in the presence of amines, bile acids and following high consumption of meat [166]. As such, certain types of clostridium species have been implicated in the progression of colon cancer and inflammatory bowel syndrome [167], whereas other types of colonic bacteria, such as bifidobacteria and lactobacilli are believed to be protective due to their low activity of mutagen generating enzymes [166]. The beneficial shift in microbial levels will also be accompanied by increased bacterial end-products, such as phenolic acids [100]. Butyrate, which is known to be involved in reducing cell apoptosis and differentiation [67, 168-172] and mainly produced by Rosburia faeces and Eubacterium rectale group [163, 173], was seen to be increased with flavanol supplementation [164].

In addition, it is possible that microbial metabolites of polyphenols may act directly on gut epithelial cancer cells to restrict their growth/proliferation [64] For example, intestinal metabolites of quercetin, chlorogenic and caffeic acids have been shown to interfere with enzymes involved in colon carcinogenesis, reducing COX-2, preventing DNA damage and by enhancing GSTT2 in colon cancer cell lines [138, 139, 145, 146]. The modification of the gut microbiota by polyphenols is likely to be a realistic way in bringing about reductions in cancer cell proliferation in the large gut although at present very few trials have been conducted to specifically test this, with only cocoa [164], blueberry [174] and wine [65] shown to induce a bifidogenic effect. Future trials testing the potential of fruits/fruit extracts to act as prebiotics are warranted and require focus on the growth of other bacteria known to be involved in colon cancer prevention $[163,173]$.

\section{Glucosinolates and colon cancer prevention}

\subsection{Structure and importance}

Glucosinolates are sulphur-rich compounds consisting of a $\beta$-D-glucopyranose residue attached via a sulphur group to a ( $Z$ )- $N$-hydroximinosulfate ester, with a side chain containing an amino acid [175]. More than 120 types of glucosinolates have been reported, and they may constitute around $10 \%$ of the seed weight. The main characteristics of these compounds reside in their odour and bitter taste and they are involved in microbial defence in plants [176]. With regards to human consumption, they are predominantly found as glycosides in Brassica vegetables, such as cabbage, Brussels sprouts, kale, broccoli, and cauliflower, whereas in Japan, radishes are considered the richest source of glucosinolates. Glucosinolates levels vary in different vegetables, with glucobrassicin and glucoraphanin found at high amounts in broccoli but to a lesser degree in cabbage, brussels sprouts and cauliflower [177], although levels are affected by climate, cultivar and soil conditions. Whilst glucosinolates are largely biologically inactive, active compounds may be generated via the release of myrosinase enzymes, during bruising, handling and mastication. The active components include nitriles, isothiocyanates and thiocyanates: notably sulforaphane and sulforaphane nitrile as a result of glucoraphanin hydrolysis, phenethyl isothiocyanates as a result of gluconasturtiin hydrolysis and indole-3carbinol as a result of glucobrassicin hydrolysis [178]. Many of these have been suggested to hold significant 
Table 4

Glucosinolates and colorectal cancers

\begin{tabular}{|c|c|c|c|}
\hline Trial & Duration & Type of food & Main results \\
\hline The Singapore Chinese health study [251] & 5 years follow up & Cruciferous vegetables & $\begin{array}{l}\text { There was an inverse association with } \\
\text { colorectal cancer risks }\end{array}$ \\
\hline $\begin{array}{l}\text { The Netherlands Cohort Study on Diet and } \\
\text { Cancer [35] }\end{array}$ & 6.3 years follow up & $\begin{array}{l}\text { Brassica vegetables and } \\
\text { cooked leafy } \\
\text { vegetables, Brussels } \\
\text { sprouts, cabbage, and } \\
\text { string beans }\end{array}$ & $\begin{array}{l}\text { An inverse association was demonstrated in } \\
\text { both genders with distal colon cancer }\end{array}$ \\
\hline $\begin{array}{l}\text { The Western Australian Bowel Health Study } \\
\text { [200] }\end{array}$ & 2 years follow up & Brassica vegetables & $\begin{array}{l}\text { An inverse association was related with the } \\
\text { proximal colon cancer }\end{array}$ \\
\hline $\begin{array}{l}\text { Epidemiological study on patients from } \\
\text { Buffalo and Kenmore [252] }\end{array}$ & 6 years follow up & $\begin{array}{l}\text { cabbage, brussels sprouts, } \\
\text { and broccoli }\end{array}$ & A decrease in the risk of colon cancer \\
\hline
\end{tabular}

chemopreventive actions against colon cancer progression [98, 179-181].

Studies have demonstrated a strong association between the consumption of cruciferous vegetables and the reduction in colorectal cancer risks (Table 4). For example, glutathione S-transferase (GST) activity has been observed to be significantly elevated in human plasma following brussels sprouts consumption [182]. GST is known to detoxify carcinogens and to suppress colon carcinogenesis [183-186]. In vitro work has supported such observations, showing that glucosinolates present in Brassica spp., such as, isothiocyanates, sulforaphane and indoles interfere with carcinogenesis [187], whilst sulforaphane is known to induce detoxification enzymes and phase II enzymes related with the metabolism and excretion of xenobiotics [188]. Furthermore, they have been observed to inhibit cell growth and a stimulate apoptosis in colon cancer cells, via the triggering increased expression of the tumour suppressor protein p-53 and an activation of the cell death programme inducers, capcase-3 [189] capcase-9 and $\mathrm{Bcl}-2$ proteins [190]. The consumption of Brassica vegetables may reduce risks of colon cancer due to its anti-cancer mechanisms [180] However, recent research on the gut microbiota must be also directed towards such types of vegetables.

\section{Dietary fibre and colon cancer prevention}

\subsection{Type, intake and metabolism}

The American Association of Cereal Chemists (AACC) defines dietary fibres as "the edible parts of plants or analogous carbohydrates that are resis- tant to digestion and absorption in the human small intestine but undergo complete or partial fermentation in the large intestine" [191]. Dietary fibre, which includes polysaccharides, oligosaccharides, lignin, and associated substances, are well known to promote beneficial physiological effects including laxation and/or blood cholesterol attenuation and/or blood glucose attenuation [192, 193]. Fibres are divided into soluble and insoluble according to their physiochemical properties. Insoluble fibres, including resistant starch, escape small intestinal digestion and absorption and pass to the colon where they are fermented by the gut microbiota. Resistant oligosaccharides, which include fructo-oligosaccharides FOS, found in onions and artichoke, inulin and galacto oligosaccharides GOS exhibit a prebiotic potential by inducing selective growth of the microbiota [63, 194, 195]. Soluble types of fibres (polysaccharides) have also been linked with changing the gut ecology, although they are more effective in lowering blood cholesterol, due to their potential to alter fat absorption [196].

Worldwide, recommendations on fibre-intake differ markedly, perhaps reflecting a lack of detailed knowledge regarding their health activity. In the UK, the recommended intake is $18 \mathrm{~g} / \mathrm{d}$, in Germany $30 \mathrm{~g} / \mathrm{d}$ and in the USA $38 \mathrm{~g} / \mathrm{d}$, for men aged $20-50$ years, whilst for women an amount of $26 \mathrm{~g} / \mathrm{d}$ is recommended in the USA [197]. As with most macro- and micro-nutrients, the intake of fibre varies within populations according to age and education [195], as well as due to differences in the definition of fibre and disparity in socioeconomic status [198]. Despite variations in intake, an increase in the intake of high-fibre foods is widely recommended to prevent chronic disease [63, 193]. 
Table 5

Dietary fibres and colorectal cancers

\begin{tabular}{|c|c|c|c|}
\hline Trial & Duration & Type of food & Main results \\
\hline $\begin{array}{l}\text { The European prospective } \\
\text { investigation into cancer and } \\
\text { nutrition (EPIC) [253] }\end{array}$ & 11 years follow up & $\begin{array}{l}\text { Dietary fibres from cereals, } \\
\text { fruits and vegetables }\end{array}$ & $\begin{array}{l}\text { An inverse association between fibre intake } \\
\text { and colon cancer was seen }\end{array}$ \\
\hline $\begin{array}{l}\text { The European Prospective } \\
\text { Investigation into Cancer and } \\
\text { Nutrition (EPIC), } 2003 \text { [39] }\end{array}$ & 4.5 years follow up & $\begin{array}{l}\text { Dietary fibres; Cereals were } \\
\text { the main sources of fibre in } \\
\text { the Netherlands, Germany, } \\
\text { Sweden, and Denmark, } \\
\text { whereas vegetables were } \\
\text { most important in France } \\
\text { and the UK. Fruit was an } \\
\text { important source of fibre in } \\
\text { Italy and Spain. Legumes } \\
\text { and potatoes contributed } \\
\text { small amounts and were } \\
\text { more important in Spain, } \\
\text { the Netherlands, and } \\
\text { Denmark. }\end{array}$ & $\begin{array}{l}\text { An inverse association was mostly seen in } \\
\text { the colon rather than the rectum }\end{array}$ \\
\hline $\begin{array}{l}\text { Case-control studies conducted in } \\
\text { northern Italy [68] }\end{array}$ & 18 years follow up & Dietary fibres & $\begin{array}{l}\text { There was an inverse association with colon } \\
\text { cancer }\end{array}$ \\
\hline $\begin{array}{l}\text { Population-based study in Murcia in } \\
\text { Spain and Copenhagen in the } \\
\text { Denmark [254] }\end{array}$ & 5 years follow up & Fibre intake & $\begin{array}{l}\text { Fibre intake in Spanish population was } 31 \% \\
\text { higher than Denmark populations, which } \\
\text { was mainly from non-starch } \\
\text { polysaccharides. A reduction of colon } \\
\text { cancer in Murcia was also observed }\end{array}$ \\
\hline $\begin{array}{l}\text { Population-based prospective } \\
\text { mammography study of Swedish } \\
\text { women [24] }\end{array}$ & 9.6 years follow up & Fibre intake & No association was found with cereal fibres \\
\hline $\begin{array}{l}\text { The prospective Scandinavian } \\
\text { HELGA cohort [255] }\end{array}$ & 11.3 years follow up & $\begin{array}{l}\text { Fibre intake in vegetables, } \\
\text { fruits, potatoes, and cereals }\end{array}$ & $\begin{array}{l}\text { There was a significant association in } \\
\text { reducing risk of colon cancer but not rectal } \\
\text { cancers with total fibre intake and cereal } \\
\text { fibres in particularly }\end{array}$ \\
\hline $\begin{array}{l}\text { A prospective study on women with } \\
\text { no history of colon cancer [211] }\end{array}$ & 16 year follow up & Fibre intake & There was no association with colon cancer \\
\hline
\end{tabular}

\subsection{In vivo and in vitro studies}

Strong observation data have demonstrated that dietary fibre intake may reduce the risk of CRC in various populations (Table 5), which was also been seen in relation to fruit and vegetable consumption (Table 1). Early reports that highlighted dietary fibre as having beneficial actions in the large gut also suggested that there may be significant reductions possible in CRC risk [30, 192]. Insoluble fibre are well reported to increase the faecal bulk and to reduce transit time, resulting in the dilution of toxin concentrations and the duration of potential carcinogen exposure to the colonic epithelial mucosa [193]. Indeed, dietary fibre has been shown to have a laxative potential in constipated patients [199]. Furthermore, fibre intake has been shown to reduce DNA damage and genotoxic components in healthy volunteers [200] and in polypectomized and CRC patients [201-203]. In addition, resistant starch consumption reduces secondary bile acids concentration in the gut in patients with colonic lesions [196, 204]. As discussed earlier, dietary choices will greatly influence fibre intake and thus its potential protective effects. For example, consuming less meat usually correlates with increased fibre intake $[30,205]$. 
With regards to prebiotics (xylooligosaccharides $\&$ fructooligosaccharides) and synbiotics (bifidobacterium longum and lactulose), significant declines in aberrant crypt foci (ACF) numbers in animal models have been observed [49, 206, 207]. Similar outcomes have been observed with diets containing different types of fibres, such as resistant starch [208] and wheat bran [209], where reductions in tumour mass has been observed [51]. Cell studies with fibres are perhaps more difficult to interpret, as the addition of unfermented fibres to cells in culture has limited physiological significance. However, in vitro data suggest different mechanisms of action for the inhibitory effects of fibres on the growth of colon cancer cells, with reductions in colonocytes DNA damage [22, 170, 207] thought to be involved. There are other biomarkers, involved in CRC progression which also need to be considered, including bile acids, n-nitroso-compounds and calcium [210]. However, to date intervention studies regarding the effects of fruit and vegetable fibres on CRC risk are scarce [211, 212], with almost all studies conducted using broad fruit and vegetable intake and very few looking at the effects of specific fibre-rich ones, such as Jerusalem artichoke rich which is rich in fructo-oligosaccharides [213]. Therefore, future trials should be directed at the use of specific high fibre fruits and vegetables and/or specific fibre interventions to shed further light on their specific anti-cancer potential.

\subsection{Impact of shifting the bacterial population favourably on cancer risk}

There have been many investigations into the influence diets rich in fibres or prebiotics have on the selective growth of the microbiota (Table 6), including FOS, inulin, lactulose, oligofructose, resistant starch and different types of whole grains, all of which exert significant increases in the growth of bifidobacteria and lactobacilli and smaller changes in Bacteroides, Clostridium subgroups, Eubacterium, enterecocci, and ruminococcus [165, 213-217]. Such human data is supported by animal studies [218] and in pH-controlled batch culture experiments [219-223]. In such trials, other bacterial fermentation biomarkers were also investigated, including stool weight and breath-hydrogen excretion, which alter due to alterations in the microbial ecology and/or resultant carbohydrate fermentation [154, 224]. Some studies suggest that the fermentation of fibre found in fruits and vegetables is significantly quicker and more extensive than that found in grains $[159,166]$, suggesting that the consumption of fruits and vegetables may have at least as good a potential to modulate the gut microbiota in a favourable way.

There is still a debate as to whether dietary fibre is involved in preventing CRC [211, 212], even though fibres intake has been implicated in reducing CRC risks by around $25 \%$ [39]. The saccharolytic fermentation of carbohydrates by the microbiota results in the formation of short chain fatty acids (SCFAs), such as acetate, propionate and butyrate, which were found to exert various anti-cancer effects in transformed/initiated cells in vitro [67, 168-172]. They have been postulated to do this through their ability to down regulate enzymes involved in carcinogenesis, such as glutathione S-transferases (GST) [171] and alkaline phosphatase (AP), to interfere with the cancer cell proliferation [225] and to induce apoptosis in colon cancer cell lines [22, 67, 226-229]. Such observations have been detected using butyrate and propionate at less than $2 \mathrm{mM}$, which are considered to be physiologically relevant [230]. Elsewhere, in vitro data indicate that butyrate down regulate cyclin B1 CB1 and increasing $p$-21 cell-cycle inhibitor, which all resulted in cell apoptosis [169, 231]. With regards to the MAPK kinases, butyrate was shown to inhibit the JNK MAKP, rather than the p38 pathway, in colon cancer cell lines [172].

Despite the wealth of positive data which suggest an anti-cancer effect, some studies are less positive, possibly due to variability in the diets administered [232, 233] and age of participants [234]. In addition, human data are required in order to fully assess the anti-cancer potential of fibre-rich foods in vivo. There is little doubt that dietary fibre has the potential to positively alter the colonic microbiota and metabolite levels in a way that should enhance the gut health. Indeed, good data have been observed with lactulose [217], oligofructose and inulin [235]. Other studies have shown the prebiotic potential of fibres supplemented into biscuits [214] and bars [216]. However, although not specifically tested, the consumption of fibre-containing fruits and vegetables may also be effective, with blueberry having a significant impact in modulating the gut ecology into a healthier one [174] and Jerusalem artichoke and chicory intake shown to have bifidogenic ability [216]. Ideally, the selection of a natural food source that contains fibres (with identification of a prebiotic potential) and polyphenols will be interesting to test in 
Table 6

Dietary fibres and the gut microbiota

\begin{tabular}{|c|c|c|c|}
\hline Trial & Duration & Type of food & Main results \\
\hline $\begin{array}{l}\text { A randomized, controlled, } \\
\text { double-blind, crossover } \\
\text { intervention study [165] }\end{array}$ & & $\begin{array}{l}\text { Whole grain cereals WG } \\
\text { Whole bran cereals WB }\end{array}$ & $\begin{array}{l}\text { Significant increase in bifidobacteria and lactobacilli, } \\
\text { was seen more with WG than WB }\end{array}$ \\
\hline $\begin{array}{l}\text { A randomized, controlled, } \\
\text { double-blind, crossover } \\
\text { intervention study [173] }\end{array}$ & & Polydextrose PDX & $\begin{array}{l}\text { Significant increase in ruminococcus intestinalis and } \\
\text { some clostridium clusters, and a decrease in } \\
\text { lactobacillus-enterococcus species }\end{array}$ \\
\hline $\begin{array}{l}\text { A randomized, controlled, } \\
\text { double-blind, crossover } \\
\text { intervention study [214] }\end{array}$ & $\begin{array}{l}3 \text { weeks } \\
\text { treatments }\end{array}$ & $\begin{array}{l}\text { Partially hydrolysed guar gum } \\
\text { PHGG biscuit } \\
\text { Fructo-oligosaccharides FOS biscuit }\end{array}$ & $\begin{array}{l}\text { Significant increase was seen in bifidobacteria with } \\
\text { PHGG and FOS biscuits }\end{array}$ \\
\hline $\begin{array}{l}\text { A randomized, controlled, } \\
\text { double-blind, crossover } \\
\text { intervention study [256] }\end{array}$ & $\begin{array}{l}\text { Between } 26 \\
\text { to } 33 \text { days }\end{array}$ & Lactulose powder & $\begin{array}{l}\text { Significant increase in bifidobacteria and lactobacilli, } \\
\text { and a decrease in clostridia was seen }\end{array}$ \\
\hline $\begin{array}{l}\text { A randomized, controlled, } \\
\text { double-blind, crossover } \\
\text { intervention study [217] }\end{array}$ & 6 weeks treatment & Lactulose & Significant increase in bifidobacteria \\
\hline $\begin{array}{l}\text { A randomized, controlled, } \\
\text { double-blind, crossover } \\
\text { intervention study [215] }\end{array}$ & 7 days treatment & $\begin{array}{l}\text { Non digestible carbohydrates } \\
\text { NDCHs, such as, short-chain } \\
\text { fructooligosaccharides, soybean } \\
\text { oligosaccharides, } \\
\text { galacto-oligosaccharides, and type } \\
\text { III resistant starch, lactulose, } \\
\text { long-chain inulin, and } \\
\text { isomaltooligosaccharides }\end{array}$ & $\begin{array}{l}\text { Significant increase in bifidobacteria was only seen with } \\
\text { short-chain fructooligosaccharides, soybean } \\
\text { oligosaccharides, galactooligosaccharides, and type } \\
\text { III resistant }\end{array}$ \\
\hline $\begin{array}{l}\text { A randomized, controlled, } \\
\text { double-blind, crossover } \\
\text { intervention study [218] }\end{array}$ & 45 days treatment & Oligofructose and inulin & $\begin{array}{l}\text { Significant increase in bifidobacteria was seen by both } \\
\text { oligofructose and inulin. However inulin have } \\
\text { decreased gram-positive bacteria and oligofructose } \\
\text { have reduced counts of clostridia, and fusobacteria }\end{array}$ \\
\hline $\begin{array}{l}\text { A randomized, controlled, } \\
\text { double-blind, crossover } \\
\text { intervention study [254] }\end{array}$ & 21 days treatment & $\begin{array}{l}\text { Maize-derived whole grain cereal } \\
\text { WGM }\end{array}$ & Significant increase in bifidobacteria was seen by WGM \\
\hline $\begin{array}{l}\text { A randomized, controlled, } \\
\text { double-blind, crossover } \\
\text { intervention study [216] }\end{array}$ & 3 weeks & $\begin{array}{l}\text { a. snack bars without } \\
\text { supplementation of inulin } \\
\text { (placebo) } \\
\text { b. snack bars with CH chicory inulin } \\
\text { c. snack bars with JA Jerusalem } \\
\text { artichoke }\end{array}$ & $\begin{array}{l}\text { Significant increase in bifidobacteria was been by both } \\
\text { bars with } \mathrm{CH} \text { and JA, but no changes in SCFAs was } \\
\text { seen }\end{array}$ \\
\hline $\begin{array}{l}\text { A randomized, controlled, } \\
\text { double-blind, crossover } \\
\text { intervention study [257] }\end{array}$ & 3 weeks & $\begin{array}{l}\text { Shots of pear-carrot-sea buckthorn } \\
\text { (PCS) or plum-pear-beetroot } \\
\text { (PPB), containing Jerusalem } \\
\text { artichoke (JA) inulin }\end{array}$ & $\begin{array}{l}\text { Significant increases in both bifidobacteria and } \\
\text { lactobacillus were seen }\end{array}$ \\
\hline $\begin{array}{l}\text { A randomized, controlled, } \\
\text { double-blind crossover } \\
\text { intervention study [258] }\end{array}$ & 3 weeks & $\begin{array}{l}\text { Wheat/rye bread with or without } \\
\text { Arabinoxylan oligosaccharides } \\
\text { (AXOS) }\end{array}$ & Significant increase in bifidobacteria \\
\hline $\begin{array}{l}\text { A randomized, controlled, } \\
\text { double-blind crossover } \\
\text { intervention study [259] }\end{array}$ & 3 weeks & $\begin{array}{l}\text { Bread enriched with Arabinoxylan } \\
\text { oligosaccharides (AXOS) }\end{array}$ & $\begin{array}{l}\text { Limited changes were seen with AXOS-breads, whereas } \\
\text { bifidobacteria elevated following control breads } \\
\text { consumption }\end{array}$ \\
\hline
\end{tabular}


human trials and such an approach may be required in future.

\section{Summary and future perspectives}

The intake of at least 5 different $80 \mathrm{~g}$ portions of fruits and vegetables a day is encouraged for the prevention of cancer. However, on-going observational studies have concluded that the link between fruit and vegetable intake and colorectal cancer incidence in weaker than originally thought. Why is this? As food intake assessment has improved, the fruit and vegetable intake data available in such studies has become more extensive and included a wider range of individual items. However, rather than being a good thing, we suggest that the weakening association between the intake of fruits and vegetables and cancer may lie in the notion that all fruits and vegetables are not equal in their anti-cancer potential, notably due to their widely different levels of fibre and/or polyphenols. The inclusion of certain 'inactive' fruits and vegetables in calculations relating to a reduction in cancer risk would be expected to weaken such an association. We suggest that there are specific fruits and vegetables that have specific potency with regards to preventing colorectal cell initiation and progression and that this potential is underpinned by their fibre and polyphenol content and the effects these have on gut epithelial cells and the microbiota. In other words, population level advice to increase fruit and vegetable intake generally is likely to be less effective in bringing about a reduction in GI tract cancer than an approach which targets those fruits and vegetables which contain the highest levels of fibre/polyphenols and which have been demonstrated to exert anti-cancer effects in various systems.

It seems likely that fruits and vegetables capable of delivering high amounts of fibres, such as, pears, apples, and berries [236], or high levels of polyphenols, such as, blueberries, strawberries and grapes [119] and dried fruits, such as date fruits [237], figs, and plums [199], or indeed high levels of both [238], such as apples [203, 204], oranges [239], date fruits [237, 240], and Brassica vegetables [96] might have the greatest potential to induce reductions in colon cancer development/progression. We predict that the inclusion of such foods in clinical trials aimed at investigating the impact of fruits and vegetables intake on bowel cancer development is likely to yield a stronger inverse relationship between these two factors relative to that observed following board, non-descriptive fruit and vegetable intake supplementation. The concentration of polyphenols and fibres found within these specific fruits and vegetables, will deliver high levels of bioactive compounds to the intestinal epithelium where they may act to inhibit cancer cell proliferation and induce cancer cell apoptosis.

With regards to future avenues of investigation, there is certainly a lack of data regarding the effects of specific polyphenols and/or polyphenol-rich foods on the specific growth of the microbiota? Therefore, studies aimed at understanding the influences of polyphenols on the microbiota should be undertaken both in mixed, $\mathrm{pH}$ controlled culture vessels and in human clinical studies. Furthermore, whilst it is reasonably well understood how polyphenols are metabolised by the microbiota to produce smaller phenolic acids [115] (akin to SCFAs if carbohydrates are used as substrates), to date, few, if any, studies have considered the positive effects of such metabolites on cancer cell fate and related mechanisms of action. In the course of such experiments, and particularly with relation to in vitro batch culture studies, one should give thought to the realistic amounts of polyphenols (delivered by foods) that reach the large intestine. In this respect, analytical methods to measure polyphenol metabolites (including the application metabonomics and metabolomics) in the circulation have greatly improved and such methodology should be applied to the measurement of phenolic metabolites formed in the large gut.

Regarding the actions of polyphenols on cancer cells in the large intestine, the data are also quite unclear. Whilst there have been various investigations of the influence of polyphenols on the proliferation of colonic cancer cells and their potential to induce apoptosis, few of these have considered whether such activity is modified by the metabolism of these compounds by the resident bacteria. This is critical, as polyphenols entering the large intestine will be subject to rapid degradation meaning that large intestinal epithelial cells will rarely, if ever, be exposed to native polyphenol compounds. Rather the smaller phenolic acid metabolic products are expected to dominate in the small intestine and it is within these that the anticancer potential should be assessed [241]. With regards to dietary fibre, although the impact of these on the gut microbiota is well established, the persistence of these effects is unclear. In addition, the combined actions of both dietary fibres and polyphenols on colon health are unknown at present. As both are found at reasonable 


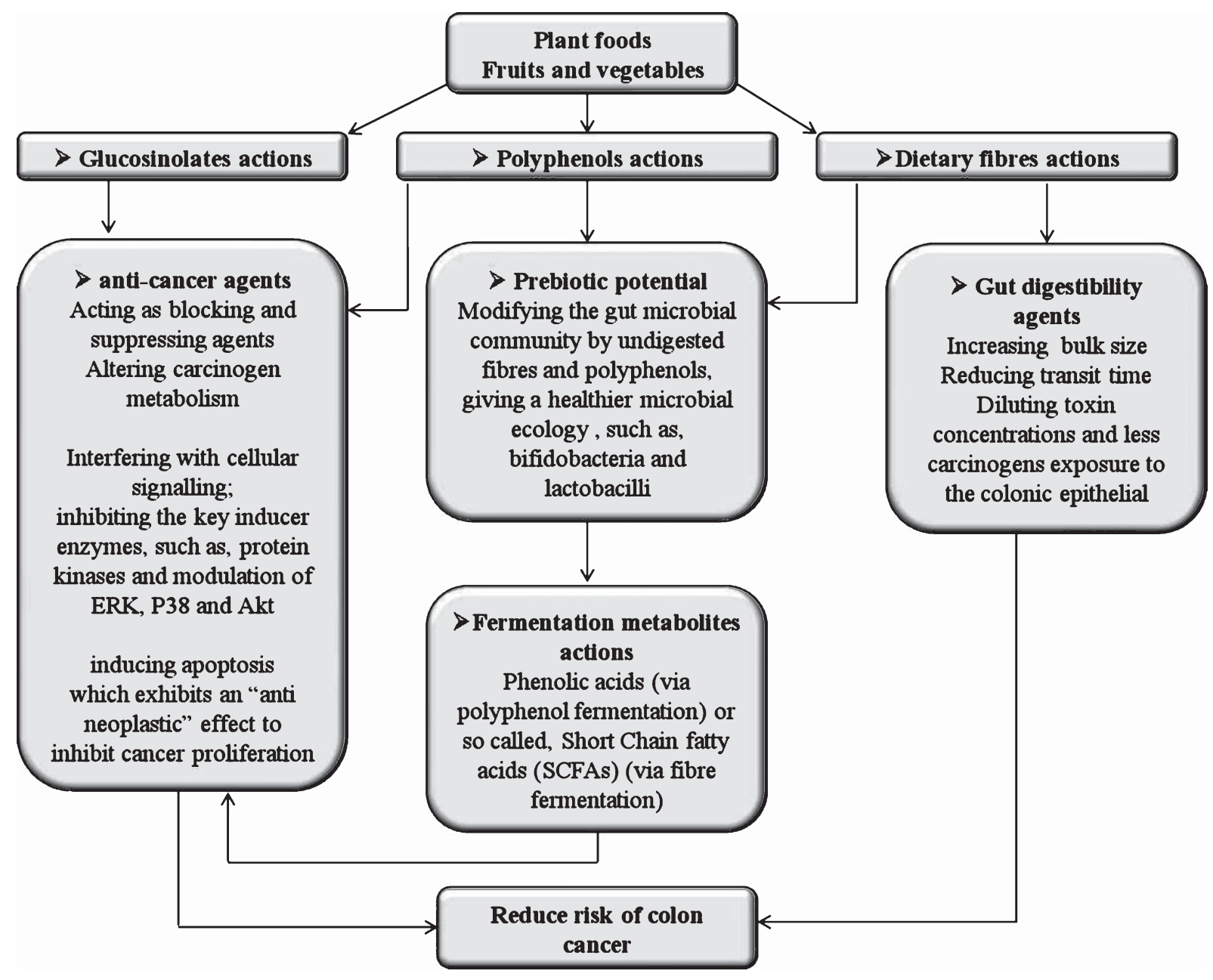

Fig. 2. Fruits, vegetables and colon cancer prevention.

quantities in the foods we have outlined in this review (apple and other stone fruits, orange and other citrus fruits, dates, raisons and other dried fruits and Brassica vegetables), future human trials to assess the influence of such foods on anti-cancer activities at the cellular and microbiological level are warranted.

Additionally, nutrigenomics may also be an important factor when assessing the potential reaction of humans towards specific diets or dietary agents [242]. Recent research has highlighted many potential risk factors for colorectal cancers, including that of obesity [16]. In vitro data suggest that obesity hormones such as leptin may enhance colon cancer progression [57], something also observed in animal models [58]. Such factors may influence the potential benefits of polyphenol/fibre rich fruits and vegetables in human populations, along with a host of other genetic factors associated with cancer development. As such, the degree of protection afforded by polyphenol/fibre-rich diets may be altered either favourably or unfavourably when combined with such genetic and/or lifestyle factors. Finally, aging is one of the strongest risks factors for cancer progression, with over than $90 \%$ of people diagnosed with colorectal cancer being over 50 years of age. Such a statistic is likely associated DNA oxidation/methylation, processes which is directly involved in cancer development [59]. Therefore, it would be of interest to compare the influence of fruit and vegetable interventions on individuals of different ages, most notably above and below 50, where modulation of early DNA damage may have real potential to prevent mutagenesis and progression to cancer cell phenotypes. 


\section{References}

[1] Gonzalez CA, Riboli E. Diet and cancer prevention: Contributions from the European Prospective Investigation into Cancer and Nutrition (EPIC) study. European Journal of Cancer. 2010;46(14):2555-62.

[2] Ferlay J, Shin H-R, Bray F, Forman D, Mathers C, Parkin DM. Estimates of worldwide burden of cancer in 2008: GLOBOCAN 2008. International Journal of Cancer. 2010;127(12):2893-917.

[3] Jemal A, Bray F, Center MM, Ferlay J, Ward E, Forman D. Global cancer statistics. CA: A Cancer Journal for Clinicians. 2011;61(2):69-90.

[4] Durai R, Yang SY, Seifalian AM, Winslet MC. Principles and applications of gene therapy in colon cancer. J Gastrointestin Liver Dis. 2008;17(1):59-67.

[5] Sanyal U. Stamping out cancer. Br J Cancer. 2003;89(12): 2165-71.

[6] Fung T, Brown L. Dietary Patterns and the Risk of Colorectal Cancer. Current Nutrition Reports. 2012:1-8.

[7] Djuric Z, Severson RK, Kato I. Association of dietary quercetin with reduced risk of proximal colon cancer. Nutrition and Cancer. 2012;64(3):351-60.

[8] Weinberg RA. The Biology of Cancer. New York: Garland Science; 2007.

[9] Bujanda, Cosme A, Gil I, Arenas-Mirave JI. Malignant colorectal polyps. World J Gastroenterol. 2010;16(25):3103-11.

[10] Mishra J, Drummond J, Quazi SH, Karanki SS, Shaw JJ, Chen $\mathrm{B}$, et al. Prospective of colon cancer treatments and scope for combinatorial approach to enhanced cancer cell apoptosis. Critical Reviews in Oncology/Hematology. 2012(0).

[11] Davis CD, Milner JA. Gastrointestinal microflora, food components and colon cancer prevention. The Journal of Nutrition biochemistry. 2009;20(10):743-52.

[12] Fearon ER. Molecular Genetics of Colorectal Cancer. Annual Review of Pathology: Mechanisms of Disease. 2011;6(1): 479-507.

[13] Gordon MA, Zhang W, Yang D, Iqbal S, El-Khouiery A, Nagashima F, et al. Gender-specific genomic profiling in metastatic colorectal cancer patients treated with 5fluorouracil and oxaliplatin. Pharmacogenomics. 2011;12(1): 27-39.

[14] Regula J, Rupinski M, Kraszewska E, Polkowski M, Pachlewski J, Orlowska J, et al. Colonoscopy in Colorectal-Cancer Screening for Detection of Advanced Neoplasia. N Engl J Med. 2006;355(18):1863-72.

[15] Zhang H, Zhang M, Yu L, Zhao Y, He N, Yang X. Antitumor activities of quercetin and quercetin- $5^{\prime}, 8$-disulfonate in human colon and breast cancer cell lines. Food and Chemical Toxicology. 2012;50(5):1589-99.

[16] Doubeni CA, Major JM, Laiyemo AO, Schootman M, Zauber AG, Hollenbeck AR, et al. Contribution of Behavioral Risk Factors and Obesity to Socioeconomic Differences in Colorectal Cancer Incidence. Journal of the National Cancer Institute. 2012;104(18):1353-62.

[17] Andaya AA, Enewold L, Zahm SH, Shriver CD, Stojadinovic A, McGlynn KA, et al. Race and Colon Cancer Survival in an Equal-Access Healthcare System. Cancer Epidemiol Biomarkers Prev. 2013.
[18] Giovannucci E, Rimm E, Ascherio A, Stampfer M, CGaW W. Alcohol, low-methionine-folate diets, and risk of colon cancer in men. J Natl Cancer Inst. 1995;87:265-73.

[19] Leufkens AM, Van Duijnhoven FJB, Siersema PD, Boshuizen HC, Vrieling A, Agudo A, et al. Cigarette Smoking and Colorectal Cancer Risk in the European Prospective Investigation Into Cancer and Nutrition Study. Clinical Gastroenterology and Hepatology. 2011;9(2):137-44.

[20] Ruder EH, Thiébaut AC, Thompson FE, Potischman N, Subar AF, Park Y, et al. Adolescent and mid-life diet: Risk of colorectal cancer in the NIH-AARP Diet and Health Study. The American Journal of Clinical Nutrition. 2011;94(6): 1607-19.

[21] Williamson G, Manach C. Bioavailability and bioefficacy of polyphenols in humans. II. Review of 93 intervention studies. The American Journal of Clinical Nutrition. 2005;81(1):243S-55S

[22] Rosignoli P, Fabiani R, De Bartolomeo A, Fuccelli R, Pelli M, Morozzi G. Genotoxic effect of bile acids on human normal and tumour colon cells and protection by dietary antioxidants and butyrate. European Journal of Nutrition. 2008;47(6): 301-9.

[23] Sanderson P, Johnson IT, Mathers JC, Powers HJ, Downes CS, McGlynn AP, et al. Emerging diet-related surrogate end points for colorectal cancer: UK Food Standards Agency diet and colonic health workshop report. British Journal of Nutrition. 2004;91(02):315-22.

[24] Terry P, Giovannucci E, Michels KB, Bergkvist L, Hansen H, Holmberg L, et al. Fruit, Vegetables, Dietary Fiber, and Risk of Colorectal Cancer. J Natl Cancer Inst. 2001a;93(7):525-33.

[25] Padidar S, Farquharson A, Williams L, Kearney R, Arthur J, Drew J. High-Fat Diet Alters Gene Expression in the Liver and Colon: Links to Increased Development of Aberrant Crypt Foci. Digestive Diseases and Sciences. 1-9.

[26] Bastide NM, Pierre FHF, Corpet DE. Heme Iron from Meat and Risk of Colorectal Cancer: A Meta-analysis and a Review of the Mechanisms Involved. Cancer Prevention Research. 2011;4(2):177-84

[27] Oba S, Shimizu N, Nagata C, Shimizu H, Kametani M, Takeyama N, et al. The relationship between the consumption of meat, fat, and coffee and the risk of colon cancer: A prospective study in Japan. Cancer Letters. 2006;244(2): 260-7.

[28] Fu Z, Shrubsole MJ, Smalley WE, Wu H, Chen Z, Shyr Y, et al. Association of meat intake and meat-derived mutagen exposure with the risk of colorectal polyps by histologic type. Cancer Prev Res (Phila) 2011;4(10):1686-97.

[29] Van der Meer R, Lapré JA, Govers MJAP, Kleibeuker $\mathrm{JH}$. Mechanisms of the intestinal effects of dietary fats and milk products on colon carcinogenesis. Cancer Letters. 1997;114(1-2):75-83.

[30] Burkitt DP. Epidemiology of cancer of the colon and rectum. Cancer 1971;28:3-13.

[31] Riboli E, Norat T. Epidemiologic evidence of the protective effect of fruit and vegetables on cancer risk. Am J Clin Nutr. 2003;78(3):559S-69.

[32] Van Duijnhoven FJ, Bueno-De-Mesquita HB, Ferrari P, Jenab M, Boshuizen HC, Ros MM, et al. Fruit, vegetables, and colorectal cancer risk: The European Prospective Investigation 
into Cancer and Nutrition. Am J Clin Nutr. 2009;89(5):144152.

[33] Shibata A, Paganini-Hill A, Ross RK, Henderson BE. Intake of vegetables, fruits, beta-carotene, vitamin $\mathrm{C}$ and vitamin supplements and cancer incidence among the elderly: A prospective study. Br J Cancer. 1992;66:673-9.

[34] Thun MJ, Calle EE, Namboodiri MM, Flanders WD, Coates RJ, Byers T, et al. Risk Factors for Fatal Colon Cancer in a Large Prospective Study. J Natl Cancer Inst. 1992;84(19): 1491-500.

[35] Voorips LE, Goldbohm RA, van Poppel G, Sturmans F, Hermus RJJ, van den Brandt PA. Vegetable and Fruit Consumption and Risks of Colon and Rectal Cancer in a Prospective Cohort Study The Netherlands Cohort Study on Diet and Cancer. Am J Epidemiol. 2000;152(11):1081-92.

[36] Trichopoulou A, Bamia C, Trichopoulos D. Anatomy of health effects of Mediterranean diet: Greek EPIC prospective cohort study. BMJ. 2009;338(jun23_2):b2337.

[37] Ruder EH, Thiébaut AC, Thompson FE, Potischman N, Subar AF, Park Y, et al. Adolescent and mid-life diet: Risk of colorectal cancer in the NIH-AARP Diet and Health Study. The American Journal of Clinical Nutrition. 2011;94(6):1607-19.

[38] Aune D, Lau R, Chan DSM, Vieira R, Greenwood DC, Kampman E, et al. Nonlinear Reduction in Risk for Colorectal Cancer by Fruit and Vegetable Intake Based on Meta-analysis of Prospective Studies. Gastroenterology. 2011;141(1):10618.

[39] Bingham SA, Day NE, Luben R, Ferrari P, Slimani N, Norat $\mathrm{T}$, et al. Dietary fibre in food and protection against colorectal cancer in the European Prospective Investigation into Cancer and Nutrition (EPIC): An observational study. The Lancet. 2003;361(9368):1496-501.

[40] Akhter M, Iwasaki M, Yamaji T, Sasazuki S, Tsugane S. Dietary isoflavone and the risk of colorectal adenoma: A case-control study in Japan. Br J Cancer. 2009;100(11): 1812-6.

[41] Evropi Theodoratou, Janet Kyle, Roseanne Cetnarskyj, Susan M. Farrington AT, Rebecca Barnetson, Mary Porteous, et al. Dietary Flavonoids and the Risk of Colorectal Cancer. Cancer Epidemiology, Biomarkers \& Prevention. 2007;16(4):68493.

[42] Kyle JAM, Sharp L, Little J, Duthie GG, McNeill G. Dietary flavonoid intake and colorectal cancer: A case? control study. British Journal of Nutrition. 2010;103(03):429-36.

[43] Aldoori W, Ryan-Harshman M. Preventing diverticular disease. Review of recent evidence on high-fibre diets. Canadian Family Physician. 2002;48(10):1632-7.

[44] Key TJ, Schatzkin A, Willett WC, Allen NE, Spencer EA, Travis RC. Diet, nutrition and the prevention of cancer. Public Health Nutrition. 2004;7(1a):187-200.

[45] Doll R, R. P. The Cause of Cancer. New York: Oxford University Press. 1981.

[46] Sesink A. Red Meat and Colon Cancer. Cancer research (Baltimore). 1999;59(22):5704.

[47] Kuhnle GGC, Bingham SA. Dietary meat, endogenous nitrosation and colorectal cancer. Biochemical Society Transactions. 2007;035(5):1355-7.

[48] Lin J, Zhang SM, Wu K, Willett WC, Fuchs CS, Giovannucci E. Flavonoid Intake and Colorectal Cancer Risk in Men and Women. Am J Epidemiol. 2006;164(7): 644-51.

[49] Pool-Zobel B, van Loo J, Rowland I, Roberfroid MB. Experimental evidences on the potential of prebiotic fructans to reduce the risk of colon cancer. British Journal of Nutrition. 2002;87(SupplementS2):S273-S81.

[50] Matsunaga K, Katayama M, Sakata K, Kuno T, Koujiro, Yoshida, et al. Inhibitory Effects of Chlorogenic Acid on Azoxymethane-induced Colon Carcinogenesis in Male F344 Rats. Asian Pacific J Cancer. 2002;3:163-6.

[51] Mclntyre A, Gibson PR, Young GP. Butyrate production from dietary fibre and protection against large bowel cancer in a rat model. Gut 1993;34:386-91

[52] Lee SYH, Munerol B, Pollard S, Youdim KA, Pannala AS, Kuhnle GGC, et al. The reaction of flavanols with nitrous acid protects against $\mathrm{N}$-nitrosamine formation and leads to the formation of nitroso derivatives which inhibit cancer cell growth. Free radical biology \& medicine. 2006;40(2): 323-34.

[53] Hashim YZHY, Rowland IR, McGlynn H, Servili M, Selvaggini $R$, Taticchi A, et al. Inhibitory effects of olive oil phenolics on invasion in human colon adenocarcinoma cells in vitro. International Journal of Cancer. 2008;122(3):495500.

[54] Doll R, Peto R, Boreham J, Sutherland I. Mortality in relation to smoking: 50 years' observations on male British doctors. BMJ. 2004;328(7455):1519.

[55] Yamada K, Araki S, M T. Case-control study of colorectal carcinoma in situ and cancer in relation to cigarette smoking and alcohol use (Japan). Cancer Causes Control. 1997;8:78.

[56] Glynn SA, Albanes D, Pietinen P, Brown CC, Rautalahti M, Tangrea JA, et al. Colorectal cancer and folate status: A nested case-control study among male smokers. Cancer Epidemiol Biomarkers Prev. 1996;5:487-94.

[57] Bartucci M, Svensson S, Ricci-Vitiani L, Dattilo R, Biffoni $\mathrm{M}$, Signore M, et al. Obesity hormone leptin induces growth and interferes with the cytotoxic effects of 5-fluorouracil in colorectal tumor stem cells. Endocrine-Related Cancer. 2010;17(3):823-33

[58] Liu Z, Brooks RS, Ciappio ED, Kim SJ, Crott JW, Bennett G, et al. Diet-induced obesity elevates colonic TNF- $\alpha$ in mice and is accompanied by an activation of Wnt signaling: A mechanism for obesity-associated colorectal cancer. The Journal of Nutritional Biochemistry. 2012;23(10):1207-13.

[59] Ahuja N, Li Q, Mohan AL, Baylin SB, Issa J-PJ. Aging and DNA Methylation in Colorectal Mucosa and Cancer. Cancer Research. 1998;58(23):5489-94.

[60] Bauza E. Date palm kernel extract exhibits antiaging properties and significantly reduces skin wrinkles. International Journal of Tissue Reactions 2002;24:131-6.

[61] Rendeiro C, Vauzour D, Kean R, Butler LT, Rattray M, Spencer JP, et al. Blueberry supplementation induces spatial memory improvements and region-specific regulation of hippocampal BDNF mRNA expression in young rats. Psychopharmacology (Berl). 2012;223(3):319-30.

[62] Rabiu BA, Gibson GR. Carbohydrates: A limit on bacterial diversity within the colon. Biological Reviews. 2002;77(03): 443-53. 
[63] Brownawell AM, Caers W, Gibson GR, Kendall CWC, Lewis KD, Ringel Y, et al. Prebiotics and the Health Benefits of Fiber: Current Regulatory Status, Future Research, and Goals. The Journal of Nutrition. 2012;142(5):962-74.

[64] Davis CD, Milner JA. Gastrointestinal microflora, food components and colon cancer prevention. The Journal of Nutritional Biochemistry. 2009;20(10):743-52.

[65] Queipo-Ortuño MI, Boto-Ordóñez M, Murri M, GomezZumaquero JM, Clemente-Postigo M, Estruch R, et al. Influence of red wine polyphenols and ethanol on the gut microbiota ecology and biochemical biomarkers. The American Journal of Clinical Nutrition. 2012;95(6):1323-34.

[66] Wong JMW, de Souza R, Kendall CWC, Emam A, Jenkins DJA. Colonic Health: Fermentation and Short Chain Fatty Acids. Journal of Clinical Gastroenterology. 2006;40(3):23543.

[67] Hamer HM, Jonkers D, Venema K, Vanhoutvin S, Troost FJ, Brummer RJ. Review article: The role of butyrate on colonic function. Alimentary Pharmacology \& Therapeutics. 2008;27(2):104-19.

[68] Gallus S, Bosetti C, Vecchia CL. Mediterranean diet and cancer risk. European Journal of Cancer Prevention. 2004;13(5):447-52.

[69] Rose R, Bode A. Biology of free radical scavengers: An evaluation of ascorbate. FASEB J. 1993;7(12):1135-42.

[70] Islam KN, O'Byrne D, Devaraj S, Palmer B, Grundy SM, Jialal I. Alpha-tocopherol supplementation decreases the oxidative susceptibility of LDL in renal failure patients on dialysis therapy. Atherosclerosis. 2000;150(1):217-24.

[71] Jackson MI, Combs GFJ. Selenium and anticarcinogenesis: Underlying mechanisms. Current Opinion in Clinical Nutrition \& Metabolic Care. 2008;11(6):718-26. 10.1097/ MCO.0b013e3283139674.

[72] Khachik F, Beecher GR, B. aGM. Separation, identification, and quantification of carotenoids in fruits, vegetables and human plasma by high performance liquid chromatography. Pure and applied chemistry. 1991;63(1):71-80.

[73] Canistro D, Croce CD, Iori R, Barillari J, Bronzetti G, Poi G, et al. Genetic and metabolic effects of gluconasturtiin, a glucosinolate derived from cruciferae. Mutation Research/Fundamental and Molecular Mechanisms of Mutagenesis. 2004;545(1-2):23-35.

[74] Cao G, Sofic E, Prior RL. Antioxidant and Prooxidant Behavior of Flavonoids: Structure-Activity Relationships. Free Radical Biology and Medicine. 1997;22(5):749-60.

[75] Birt DF, Hendrich S, Wang W. Dietary agents in cancer prevention: Flavonoids and isoflavonoids. Pharmacology \& Therapeutics. 2001;90(2-3):157-77.

[76] Ferrándiz ML, Alcaraz MJ. Anti-inflammatory activity and inhibition of arachidonic acid metabolism by flavonoids. Inflammation Research. 1991;32(3):283-8.

[77] Erdman JW Jr, Balentine D, Arab L, Beecher G, Dwyer JT, Folts J, et al. Flavonoids and Heart Health: Proceedings of the ILSI North America Flavonoids Workshop, May 31-June 1, 2005, Washington, DC. J Nutr. 2007;137(3):718S-37.

[78] Halliwell B, Gutteridge JMC. Free radicals in biology and medicine. 4th ed. Oxford: Oxford University Press; 2007.

[79] Watson RRaP, V.R. Bioactive foods in promoting health: Fruits and vegetables Amsterdam, London: Elsevier/ Academic, 2010.
[80] Rosa LAdl, Alvarez-Parrilla E, González-Aguilar GA. Fruit and vegetable phytochemicals: Chemistry, nutritional value, and stability Ames, Iowa Wiley-Blackwell, 2010.

[81] Crozier A. Plant secondary metabolites: Ocurrence, structure and role in the human diet Oxford Blackwell, 2005.

[82] Dean RT, Fu S, Stocker R, Davies MJ. Biochemistry and pathology of radical-mediated protein oxidation. Biochem J. 1997;324(15):1-18.

[83] Witte JS, Longnecker MP, Bird CL, Lee ER, Frankl HD, Haile RW. Relation of Vegetable, Fruit, and Grain Consumption to Colorectal Adenomatous Polyps. Am J Epidemiol. 1996;144(11):1015-25.

[84] Steinmetz KA, J.D. P. Vegetables, fruit, and cancer prevention: A review. J Am Diet Assoc. 1996;96(10):1027-39.

[85] Potter JD. Food, Nutrition, and the prevention of cancer: A global perspective. Washington, DC: American Institute for Cancer Research. 1997.

[86] Parkin DM, Bray F, Ferlay J, Pisani P. Global Cancer Statistics, 2002. CA Cancer J Clin. 2005;55(2):74-108.

[87] Jemal A, Siegel R, Ward E, Hao Y, Xu J, Murray T, et al. Cancer Statistics, 2008. CA Cancer J Clin. 2008;58(2):71-96.

[88] Lindsay DG, Astley SB. European research on the functional effects of dietary antioxidants - EUROFEDA. Molecular Aspects of Medicine. 2002;23(1-3):1-38.

[89] Vinson JA, Su X, Zubik L, Bose P. Phenol Antioxidant Quantity and Quality in Foods: Fruits. J Agric Food Chem. 2001;49(11):5315-21.

[90] Ogimoto I, Shibata A, Fukuda K. World Cancer Research Fund/American Institute of Cancer Research 1997 Recommendations: Applicability to Digestive Tract Cancer in Japan. Cancer Causes \& Control: Springer; 2000. p. 9-23.

[91] Liu RH. Potential Synergy of Phytochemicals in Cancer Prevention: Mechanism of Action. J Nutr. 2004;134(12): 3479S-85.

[92] Gonzalez CA, Lujan-Barroso L, Bueno-de-Mesquita HB, Jenab M, Duell EJ, Agudo A, et al. Fruit and vegetable intake and the risk of gastric adenocarcinoma: A reanalysis of the european prospective investigation into cancer and nutrition (EPIC-EURGAST) study after a longer follow-up. International Journal of Cancer. 2012;131(12):2910-9.

[93] Hooper L, Kroon PA, Rimm EB, Cohn JS, Harvey I, Le Cornu KA, et al. Flavonoids, flavonoid-rich foods, and cardiovascular risk: A meta-analysis of randomized controlled trials. The American Journal of Clinical Nutrition. 2008;88(1): 38-50.

[94] Michels KB, Giovannucci E, Joshipura KJ, Rosner BA, Stampfer MJ, Fuchs CS, et al. Prospective Study of Fruit and Vegetable Consumption and Incidence of Colon and Rectal Cancers JNCI J Natl Cancer Inst 2000;92(21):1740-52.

[95] Ivanova V, Stefova M, Vojnoski B, Dörnyei Á, Márk L, Dimovska $\mathrm{V}$, et al. Identification of polyphenolic compounds in red and white grape varieties grown in R. Macedonia and changes of their content during ripening. Food Res Int. 2011;44(9):2851-60.

[96] Smith TK, Mithen R, Johnson IT. Effects of Brassica vegetable juice on the induction of apoptosis and aberrant crypt foci in rat colonic mucosal crypts in vivo. Carcinogenesis. $2003 ; 24(3): 491-5$

[97] Thornalley PJ. Isothiocyanates: Mechanism of cancer chemopreventive action. Anti-Cancer Drugs. 2002;13(4):331-8. 
[98] Zhang Y, Talalay P. Anticarcinogenic Activities of Organic Isothiocyanates: Chemistry and Mechanisms. Cancer Research. 1994;54(7 Supplement):1976s-81s.

[99] Pietta P-G. Flavonoids as Antioxidants. Journal of Natural Products. 2000;63(7):1035-42.

[100] Del Rio D, Costa LG, Lean MEJ, Crozier A. Polyphenols and health: What compounds are involved? Nutrition, Metabolism and Cardiovascular Diseases. 2010;20(1):1-6.

[101] Bravo L. Polyphenols: Chemistry, Dietary Sources, Metabolism, and Nutritional Significance. Nutrition Reviews. 1998;56(11):317-33.

[102] Harborne JB. Methods in plant biochemistry: Plant phenolics. London Academic press; 1989.

[103] Aherne SA, O'Brien NM. Dietary flavonols: Chemistry, food content, and metabolism. Nutrition. 2002;18(1):75-81.

[104] Kühnau J. The flavonoids. A class of semi-essential food components: Their role in human nutrition. World Rev Nutr Diet. 1976;2::117-91.

[105] Scalbert A, Morand C, Manach C, Rémésy C. Absorption and metabolism of polyphenols in the gut and impact on health. Biomedecine \& Pharmacotherapy. 2002;56(6): 276-82.

[106] Thompson MD, Thompson HJ. Chapter 1 Biomedical Agriculture: A Systematic Approach to Food Crop Improvement for Chronic Disease Prevention. In: Donald LS, editor. Advances in Agronomy: Academic Press; 2009. p. 1-54.

[107] Sosulski F, Krygier K, Hogge L. Free, esterified, and insoluble-bound phenolic acids. 3. Composition of phenolic acids in cereal and potato flours. Journal of Agricultural and Food Chemistry. 1982;30(2):337-40.

[108] Spencer JPE, Abd El Mohsen MM, Minihane A-M, Mathers JC. Biomarkers of the intake of dietary polyphenols: Strengths, limitations and application in nutrition research. British Journal of Nutrition. 2008;99(01):12-22.

[109] Walle UK, Walle T. Induction of Human UDPGlucuronosyltransferase UGT1A1 by FlavonoidsStructural Requirements Drug Metab Dispos 2002;30: 564-9.

[110] Hollman PCH, van Trijp JMP, Buysman MNCP, v.d. Gaag MS, Mengelers MJB, de Vries JHM, et al. Relative bioavailability of the antioxidant flavonoid quercetin from various foods in man. FEBS Letters. 1997;418(1-2):152-6.

[111] Ross JA, Kasum CM. DIETARY FLAVONOIDS: Bioavailability, Metabolic Effects, and Safety. Annual Review of Nutrition. 2002;22(1):19-34

[112] Spencer JPE. Metabolism of Tea Flavonoids in the Gastrointestinal Tract. J Nutr. 2003;133(10):3255S-61.

[113] Kuhnle G, Spencer JPE, Schroeter H, Shenoy B, Debnam ES, Srai SKS, et al. Epicatechin and Catechin are O-Methylated and Glucuronidated in the Small Intestine. Biochemical and Biophysical Research Communications. 2000;277(2):50712.

[114] Scheline RR. CRC handbook of mammalian metabolism of plant compounds: CRC PressBoca Raton (USA); 1991.

[115] Tuohy KM, Conterno L, Gasperotti M, Viola R. Upregulating the Human Intestinal Microbiome Using Whole Plant Foods, Polyphenols, and/or Fiber. J Agric Food Chem. 2012;60(36):8776-82.

[116] Manach C, Williamson G, Morand C, Scalbert A, Remesy C. Bioavailability and bioefficacy of polyphenols in humans.
I. Review of 97 bioavailability studies. Am J Clin Nutr. 2005;81(1):230S-42.

[117] Arts ICW, Jr DRJ, Myron G, Harnack LJ, Aaron RF. Dietary Catechins and Cancer Incidence among Postmenopausal Women: The Iowa Women's Health Study (United States). Cancer Causes \& Control. 2002;13(4):373-82.

[118] Rossi M, Negri E, Talamini R, Bosetti C, Parpinel M, Gnagnarella $\mathrm{P}$, et al. Flavonoids and Colorectal Cancer in Italy. Cancer Epidemiology Biomarkers \& Prevention. 2006;15(8):1555-8.

[119] Theodoratou E, Kyle J, Cetnarskyj R, Farrington SM, Tenesa A, Barnetson R, et al. Dietary Flavonoids and the Risk of Colorectal Cancer. Cancer Epidemiology Biomarkers \& Prevention. 2007;16(4):684-93.

[120] Hoensch H, Groh B, Edler L, Kirch W. Prospective cohort comparison of flavonoid treatment in patients with resected colorectal cancer to prevent recurrence. World J Gastroenterol. 2008;14: (14):2187-93.

[121] Vinha AF, Soares MO, Herdeiro T, Machado M. Chemical composition and antioxidant activity of portuguese diospyrus kaki fruit by geographical origins. Journal of Agricultural Sciences. 2011.

[122] Nichenametla SN, Taruscio TG, Barney DL, Exon JH. A Review of the Effects and Mechanisms of Polyphenolics in Cancer. Critical Reviews in Food Science and Nutrition. 2006;46(2):161-83.

[123] Han BS, Park CB, Takasuka N, Naito A, Sekine K, Nomura E, et al. A Ferulic Acid Derivative, Ethyl 3(4'-Geranyloxy-3-methoxyphenyl)-2-propenoate, as a New Candidate Chemopreventive Agent for Colon Carcinogenesis in the Rat. Cancer Science. 2001;92(4):404-9.

[124] Wargovich MJ, Jimenez A, McKee K, Steele VE, Velasco M, Woods J, et al. Efficacy of potential chemopreventive agents on rat colon aberrant crypt formation and progression Carcinogenesis. 2000;21(6):1149-55

[125] Tanaka T, Nishikawa A, Shima H, Sugie S, Shinoda T, Yoshimi $\mathrm{N}$, et al. Inhibitory effects of chlorogenic acid, reserpine, polyprenoic acid (E-5166), or coffee on hepatocarcinogenesis in rats and hamsters. Basic Life Sci. 1990;52: 429-40.

[126] Gee JM, Hara H, Johnson IT. Suppression of Intestinal Crypt Cell Proliferation and Aberrant Crypt Foci by Dietary Quercetin in Rats. Nutrition and Cancer. 2002;43(2): 193-201.

[127] Tessitore L, Davit A, Sarotto I, Caderni G. Resveratrol depresses the growth of colorectal aberrant crypt foci by affecting bax and p21(CIP) expression. Carcinogenesis. 2000;21:1619-22.

[128] Ziegler CC, Rainwater L, Whelan J, McEntee MF. Dietary Resveratrol Does Not Affect Intestinal Tumorigenesis in ApcMin/+Mice. J Nutr. 2004;134(1):5-10.

[129] Kawabata K, Yamamoto T, Hara A, Shimizu M, Yamada Y, Matsunaga K, et al. Modifying effects of ferulic acid on azoxymethane-induced colon carcinogenesis in F344 rats. Cancer Letters. 2000;157(1):15-21.

[130] Exon JH, Magnuson BA, South EH, Hendrix K. Effect of dietary chlorogenic acid on multiple immune functions and formation of aberrant crypt foci in rats Journal of Toxicology and Environmental Health, Part A: Current Issues. 1998;53(5):375-84. 
[131] Pereira MA, Grubbs CJ, Barnes LH. Effects of the phytochemicals, curcumin and quercetin, upon azoxymethaneinduced colon cancer and 7,12-dimethylbenz[a]anthraceneinduced mammary cancer in rats. Carcinogenesis. 1996;17: 1305-11.

[132] Hagiwara A, Yoshino H, Ichihara T. Prevention by natural food anthocyanins, purple sweet potato color and red cabbage color, of 2-amino-1- methyl-6-phenylimidazo[4,5-b]pyridine $\mathrm{PhIP}$ )-associated colorectal carcino- genesis in rats initiated with 1,2-dimethylhydrazine. J Toxicol. 2002;27:57-68.

[133] Kang S-Y, Seeram NP, Nair MG, Bourquin LD. Tart cherry anthocyanins inhibit tumor development in ApcMin mice and reduce proliferation of human colon cancer cells. Cancer Letters. 2003;194(1):13-9.

[134] Williams RJ, Spencer JPE, Rice-Evans C. Flavonoids: Antioxidants or signalling molecules? Free Radical Biology and Medicine. 2004;36(7):838-49.

[135] Van der Woude H, Gliszczynska-Swiglo A, Struijs K, Smeets A, Alink GM, Rietjens IMCM. Biphasic modulation of cell proliferation by quercetin at concentrations physiologically relevant in humans. Cancer Letters. 2003;200(1):41-7.

[136] Van Erk MJ, Roepman P, Van der Lende TR, Stierum RH, Aarts JMMJG, Van Bladeren PJ, et al. Integrated assessment by multiple gene expression analysis of quercetin bioactivity on anticancer-related mechanisms in colon cancer cells in vitro. European Journal of Nutrition. 2005;44(3):143-56.

[137] Kuo S-M. Antiproliferative potency of structurally distinct dietary flavonoids on human colon cancer cells. Cancer Letters. 1996;110(1-2):41-8.

[138] Wang W, Heideman L, Chung CS, Pelling JC, Koehler KJ, Birt DF. Cell-Cycle Arrest at G2/M and Growth Inhibition by Apigenin in Human Colon Carcinoma Cell Lines. Molecular Carcinogenesis. 2000;28(2):102-10.

[139] Chen C, Shen G, Hebbar V, Hu R, Owuor ED. aKA. Epigallocatechin-3-gallate-induced stress signals in HT-29 human colon adenocarcinoma cells. Carcinogenesis. 2003; 24:1369-78.

[140] Raicht RF, Cohen BI, Fazzini EP, Sarwal AN, Takahashi M. Protective Effect of Plant Sterols against Chemically Induced Colon Tumors in Rats Cancer Res. 1980;40:403-5.

[141] Chen A-C, Donovan SM. Genistein at a Concentration Present in Soy Infant Formula Inhibits Caco-2BBe Cell Proliferation by Causing G2/M Cell Cycle Arrest. J Nutr. 2004;134(6):1303-8

[142] Yang C, Landau J, Brendel M, Daniel H. Inhibition of carcinogenesis by dietary polyphenolic compounds. Annual review of nutrition. 2001;21(1):381.

[143] Loft S, Poulsen HE. Cancer risk and oxidative DNA damage in man. Journal of Molecular Medicine. 1996;74(6): 297-312.

[144] Lambert JD, Hong J, Yang G-Y, Liao J, Yang CS. Inhibition of carcinogenesis by polyphenols: Evidence from laboratory investigations. Am J Clin Nutr. 2005;81(1):284S-91.

[145] Wenzel U, Herzog A, Kuntz S, Daniel H. Protein expression profiling identifies molecular targets of quercetin as a major dietary flavonoid in human colon cancer cells. PROTEOMICS. 2004;4(7):2160-74

[146] Murtaza I, Marra G, Schalapbach R, Patrignani A, Kunzli M, Wagner U. A preliminary investigation demonstrating the effect of quercetin on the expression of genes related to cell- cyle arrest, apoptosis and xenobiotic metabolism in human CO115 colon adenocarcinoma cells using DNA microarray. Biotechnol Appl Biochem. 2006;45:29-36.

[147] Wang W, VanAlstyne PC, Irons KA, Chen S, Stewart JW, Birt DF. Individual and Interactive Effects of Apigenin Analogs on G2/M Cell-Cycle Arrest in Human Colon Carcinoma Cell Lines. Nutrition and Cancer. 2004;48(1):106-14.

[148] Corona G, Deiana M, Incani A, Vauzour D, Assunta Dessí $\mathrm{M}$, Spencer JPE. Inhibition of p38/CREB phosphorylation and COX-2 expression by olive oil polyphenols underlies their anti-proliferative effects. Biochemical and Biophysical Research Communications. 2007;362(3):606-11.

[149] Mutoh M, Takahashi M, Fukuda K, Matsushima-Hibiya Y, Mutoh H, Sugimura T. aW, K. Suppression of cyclooxygenase-2 promoter-dependent transcriptional activity in colon cancer cells by chemopreventive agents with a resorcin-type structure Carcinogenesis 2000;21(5):959-63.

[150] O'Leary KA, Pascual-Tereasa SD, Needs PW, Bao Y-P, O'Brien NM, Williamson G. Effect of flavonoids and Vitamin E on cyclooxygenase-2 (COX-2) transcription. Mutation Research/Fundamental and Molecular Mechanisms of Mutagenesis. 2004;551(1-2):245-54.

[151] Coates E, Popa G, Gill C, McCann M, McDougall G, Stewart $\mathrm{D}$, et al. Colon-available raspberry polyphenols exhibit anticancer effects on in vitro models of colon cancer. Journal of Carcinogenesis. 2007;6(1):4.

[152] Romier-Crouzet B, Van De Walle J, During A, Joly A, Rousseau C, Henry O, et al. Inhibition of inflammatory mediators by polyphenolic plant extracts in human intestinal Caco-2 cells. Food and Chemical Toxicology. 2009; 47(6):1221-30.

[153] Rodríguez-Ramiro I, Ramos S, López-Oliva E, Agis-Torres A, Bravo L, Goya L, et al. Cocoa polyphenols prevent inflammation in the colon of azoxymethane-treated rats and in TNF- $\alpha$-stimulated Caco- 2 cells. British Journal of Nutrition. 2012; FirstView:1-10.

[154] Yu D, Cheeseman F, Vanner S. Combined oro-caecal scintigraphy and lactulose hydrogen breath testing demonstrate that breath testing detects oro-caecal transit, not small intestinal bacterial overgrowth in patients with IBS. Gut. 2011;60(3):334-40.

[155] Tzounis X, Vulevic J, Kuhnle GGC, George T, Leonczak J, Gibson GR, et al. Flavanol monomer-induced changes to the human faecal microflora. British Journal of Nutrition. 2008;99(04):782-92.

[156] Ko H-S, Jin R-D, Krishnan H, Lee S-B, Kim K-Y. Biocontrol Ability of Lysobacter antibioticus HS124 Against Phytophthora Blight Is Mediated by the Production of 4-Hydroxyphenylacetic Acid and Several Lytic Enzymes. Current Microbiology. 2009;59(6):608-15.

[157] Alakomi H-L, Puupponen-Pimiä R, Aura A-M, Helander IM, Nohynek L, Oksman-Caldentey K-M, et al. Weakening of Salmonella with Selected Microbial Metabolites of BerryDerived Phenolic Compounds and Organic Acids. Journal of Agricultural and Food Chemistry. 2007;55(10):3905-12.

[158] Radnai B, Tucsek Z, Bognar Z, Antus C, Mark L, Berente $Z$, et al. Ferulaldehyde, a Water-Soluble Degradation Product of Polyphenols, Inhibits the Lipopolysaccharide-Induced Inflammatory Response in Mice. The Journal of Nutrition. 2009;139(2):291-7. 
[159] Larrosa M, Luceri C, Vivoli E, Pagliuca C, Lodovici M, Moneti G, et al. Polyphenol metabolites from colonic microbiota exert anti-inflammatory activity on different inflammation models. Molecular Nutrition \& Food Research. 2009;53(8):1044-54.

[160] Corona G, Tzounis X, Assunta Dessí M, Deiana M, Debnam ES, Visioli F, et al. The fate of olive oil polyphenols in the gastrointestinal tract: Implications of gastric and colonic microflora-dependent biotransformation. Free Radical Research. 2006;40(6):647-58.

[161] Del Rio D, Rodriguez-Mateos A, Spencer JP, Tognolini M, Borges G, Crozier A. Dietary (Poly)phenolics in Human Health: Structures, Bioavailability, and Evidence of Protective Effects Against Chronic Diseases. Antiox Redox Signal. 2012

[162] Kemperman RA, Bolca S, Roger LC, Vaughan EE. Novel approaches for analysing gut microbes and dietary polyphenols: Challenges and opportunities. Microbiology. 2010;156(11):3224-31.

[163] Louis P, Young P, Holtrop G, Flint HJ. Diversity of human colonic butyrate-producing bacteria revealed by analysis of the butyryl-CoA:acetate CoA-transferase gene. Environmental Microbiology. 2010;12(2):304-14.

[164] Tzounis X, Rodriguez-Mateos A, Vulevic J, Gibson GR, Kwik-Uribe C, Spencer JP. Prebiotic evaluation of cocoaderived flavanols in healthy humans by using a randomized, controlled, double-blind, crossover intervention study. The American Journal of Clinical Nutrition. 2011;93(1):62-72.

[165] Costabile A, Klinder A, Fava F, Napolitano A, Fogliano V, Leonard C, et al. Whole-grain wheat breakfast cereal has a prebiotic effect on the human gut microbiota: A doubleblind, placebo-controlled, crossover study. British Journal of Nutrition 2008;99:110-20.

[166] Gorbach SL, Goldin BR. The Intestinal Microflora and the Colon Cancer Connection. Reviews of Infectious Diseases. 1990;12(ArticleType: Research-article/Issue Title: Supplement 2. International Symposium on Anaerobic Bacteria and Bacterial Infections/Full publication date: Jan.-Feb., 1990/Copyright (C 1990 Oxford University Press):S252-S61.

[167] Knight DJW, Girling KJ. Gut flora in health and disease. The Lancet. 2003;361(9371):1831

[168] Hague A, Manning AM, Hanlon KA, Hart D, Paraskeva C, Huschtscha LI. Sodium butyrate induces apoptosis in human colonic tumour cell lines in a p53-independent pathway: Implications for the possible role of dietary fibre in the prevention of large-bowel cancer. International Journal of Cancer. 1993;55(3):498-505.

[169] Hinnebusch BF, Meng S, Wu JT, Archer SY, Hodin RA. The Effects of Short-Chain Fatty Acids on Human Colon Cancer Cell Phenotype Are Associated with Histone Hyperacetylation. J Nutr. 2002;132(5):1012-7.

[170] Hovhannisyan G, Aroutiounian R, Glei M. Butyrate reduces the frequency of micronuclei in human colon carcinoma cells in vitro. Toxicology in Vitro. 2009;23(6):1028-33.

[171] Kautenburger T, Beyer-Sehlmeyer G, Festag G, Haag N, Kühler S, Küchler A, et al. The gut fermentation product butyrate, a chemopreventive agent, suppresses glutathione Stransferase theta (hGSTT1) and cell growth more in human colon adenoma (LT97) than tumor (HT29) cells. Journal of
Cancer Research and Clinical Oncology. 2005;131(10):692700.

[172] Zhang Y, Zhou L, Bao YL, Wu Y, Yu CL, Huang YX, et al. Butyrate induces cell apoptosis through activation of JNK MAP kinase pathway in human colon cancer RKO cells. Chemico-Biological Interactions. 2010;185(3):174-81.

[173] Costabile A, Fava F, Röytiö H, Forssten SD, Olli K, Klievink $\mathrm{J}$, et al. Impact of polydextrose on the faecal microbiota: A double-blind, crossover, placebo-controlled feeding study in healthy human subjects. British Journal of Nutrition. 2011; FirstView:1-11.

[174] Vendrame S, Guglielmetti S, Riso P, Arioli S, Klimis-Zacas D, Porrini M. Six-Week Consumption of a Wild Blueberry Powder Drink Increases Bifidobacteria in the Human Gut. Journal of Agricultural and Food Chemistry. 2011;59(24): 12815-20.

[175] Halkier BA, Gershenzon J. BIOLOGY AND BIOCHEMISTRY OF GLUCOSINOLATES. Annual Review of Plant Biology. 2006;57(1):303-33.

[176] Fenwick GR, Heaney RK, Mullin WJ, VanEtten CH. Glucosinolates and their breakdown products in food and food plants. C R C Critical Reviews in Food Science and Nutrition. 1982;18(2):123-201.

[177] Keck A-S, Finley JW. Cruciferous Vegetables: Cancer Protective Mechanisms of Glucosinolate Hydrolysis Products and Selenium. Integrative Cancer Therapies. 2004;3(1):5-12.

[178] Fahey JW, Zalcmann AT, Talalay P. The chemical diversity and distribution of glucosinolates and isothiocyanates among plants. Phytochemistry. 2001;56(1):5-51.

[179] Hashem FA, Motawea H, El-Shabrawy AE, Shaker K, ElSherbini S. Myrosinase Hydrolysates of Brassica oleraceae L. Var. italica Reduce the Risk of Colon Cancer. Phytotherapy Research. 2012;26(5):743-7.

[180] Verhoeven DTH, Verhagen H, Goldbohm RA, van den Brandt PA, van Poppel G. A review of mechanisms underlying anticarcinogenicity by brassica vegetables. Chemico-Biological Interactions. 1997;103(2):79-129.

[181] Lynn A, Collins A, Fuller Z, Hillman K, Ratcliffe B. Cruciferous vegetables and colo-rectal cancer. Proceedings of the Nutrition Society. 2006;65(01):135-44.

[182] Bogaards JJ, Verhagen H, Willems MI, van Poppel G, PJ. vB Consumption of Brussels sprouts results in elevated alphaclass glutathione S-transferase levels in human blood plasma. Carcinogenesis. 1994;15(5):1073-5.

[183] Smith TK, Lund EK, Johnson IT. Inhibition of dimethylhydrazine-induced aberrant crypt foci and induction of apoptosis in rat colon following oral administration of the glucosinolate sinigrin. Carcinogenesis. 1998;19(2): 267-73.

[184] Plate AYA, Gallaher DD. Effects of Indole-3-Carbinol and phenethyl isothiocyanate on colon carcinogenesis induced by azoxymethane in rats. Carcinogenesis. 2006;27(2): 287-92.

[185] Uhl M, Kassie F, Rabot S, Grasl-Kraupp B, Chakraborty A, Laky B, et al. Effect of common Brassica vegetables (Brussels sprouts and red cabbage) on the development of preneoplastic lesions induced by 2 -amino-3-methylimidazo[4,5f]quinoline (IQ) in liver and colon of Fischer 344 rats. Journal of Chromatography B. 2004;802(1):225-30. 
[186] Gamet-Payrastre L, Li P, Lumeau S, Cassar G, Dupont MA, Chevolleau S, et al. Sulforaphane, a Naturally Occurring Isothiocyanate, Induces Cell Cycle Arrest and Apoptosis in HT29 Human Colon Cancer Cells. Cancer Research. 2000;60(5):1426-33.

[187] Bonnesen C, Eggleston IM, Hayes JD. Dietary Indoles and Isothiocyanates That Are Generated from Cruciferous Vegetables Can Both Stimulate Apoptosis and Confer Protection against DNA Damage in Human Colon Cell Lines. Cancer Research. 2001;61(16):6120-30.

[188] Zhang Y, Talalay P, Cho CG, Posner GH. A major inducer of anticarcinogenic protective enzymes from broccoli: Isolation and elucidation of structure. Proceedings of the National Academy of Sciences. 1992;89(6):2399-403.

[189] Andelová H, Rudolf E, Cervinka M. In vitro antiproliferative effects of sulforaphane on human colon cancer cell line SW620. Acta Medica (Hradec Kralove). 2007;50(3):171-6.

[190] Pappa G, Lichtenberg M, Iori R, Barillari J, Bartsch H, Gerhäuser C. Comparison of growth inhibition profiles and mechanisms of apoptosis induction in human colon cancer cell lines by isothiocyanates and indoles from Brassicaceae. Mutation Research/Fundamental and Molecular Mechanisms of Mutagenesis. 2006;599(1-2):76-87.

[191] Anon. The definition of Dietary Fibre. 2001.

[192] Burkitt DP. Some Diseases Characteristic Of Modern Western Civilization. The British Medical Journal. 1973;1(5848): 274-8.

[193] Slavin JL. Position of the American Dietetic Association: Health implications of dietary fiber. J Am Diet Assoc. 2008;108(10):1716-31.

[194] Ha MA, Jarvis MC, Mann JI. A definition for dietary fibre. Eur J Clin Nutr. 2000;54(12):861-4.

[195] Van der Kamp JW. Dietary fibre: Bio-active carbohydrates for food and feed: Wageningen: Wageningen Academic Publishers, 2004.

[196] Topping DL. Soluble Fiber Polysaccharides: Effects on Plasma Cholesterol and Colonic Fermentation. Nutrition Reviews. 1991;49(7):195-203.

[197] Terry P, Hu FB, Hansen H, Wolk A. Prospective Study of Major Dietary Patterns and Colorectal Cancer Risk in Women Am J Epidemiol. 2001b;154(12):1143-9

[198] Hulshof KFAM, Brussaard JH, Kruizinga AG, Telman J, Lowik MRH. Socio-economic status, dietary intake and 10[emsp14]y trends: The Dutch National Food Consumption Survey. Eur J Clin Nutr. 2003;57(1):128-37.

[199] Vinson JA, Zubik L, Bose P, Samman N, Proch J. Dried Fruits: Excellent in Vitro and in Vivo Antioxidants. Journal of the American College of Nutrition. 2005;24(1):44-50.

[200] Annema N, Heyworth JS, McNaughton SA, Iacopetta B, Fritschi L. Fruit and Vegetable Consumption and the Risk of Proximal Colon, Distal Colon, and Rectal Cancers in a CaseControl Study in Western Australia. Journal of the American Dietetic Association. 2011;111(10):1479-90.

[201] Pool-Zobel BL, Sauer J. Overview of Experimental Data on Reduction of Colorectal Cancer Risk by Inulin-Type Fructans. The Journal of Nutrition. 2007;137(11):2580S-4S.

[202] Rafter J, Bennett M, Caderni G, Clune Y, Hughes R, Karlsson PC, et al. Dietary synbiotics reduce cancer risk factors in polypectomized and colon cancer patients. The American Journal of Clinical Nutrition. 2007;85(2):488-96.
[203] Leontowicz H, Gorinstein S, Lojek A, Leontowicz M, Číž M, Soliva-Fortuny R, et al. Comparative content of some bioactive compounds in apples, peaches and pears and their influence on lipids and antioxidant capacity in rats. The Journal of Nutritional Biochemistry. 2002;13(10):603-10.

[204] Gorinstein S, Martin-Belloso O, Lojek A, Číž M, SolivaFortuny R, Park Y-S, et al. Comparative content of some phytochemicals in Spanish apples, peaches and pears. Journal of the Science of Food and Agriculture. 2002;82(10):116670.

[205] Ferrucci LM, Sinha R, Huang WY, Berndt SI, Katki HA, Schoen RE, et al. Meat consumption and the risk of incident distal colon and rectal adenoma. Br J Cancer. 2012;106(3): 608-16.

[206] Challa A, Rao DR, Chawan CB, Shackelford L. Bifidobacterium longum and lactulose suppress azoxymethaneinduced colonic aberrant crypt foci in rats. Carcinogenesis. 1997; 18(3):517-21

[207] Burns AJ, Rowland IR. Antigenotoxicity of probiotics and prebiotics on faecal water-induced DNA damage in human colon adenocarcinoma cells. Mutation Research/Fundamental and Molecular Mechanisms of Mutagenesis. 2004;551(1-2):233-43.

[208] Fässler C, Gill CIR, Arrigoni E, Rowland I, Amadò R. Fermentation of Resistant Starches: Influence of In Vitro Models on Colon Carcinogenesis. Nutrition and Cancer. 2007; 58(1):85-92.

[209] Zoran DL, Turner ND, Taddeo SS, Chapkin RS, Lupton JR. Wheat Bran Diet Reduces Tumor Incidence in a Rat Model of Colon Cancer Independent of Effects on Distal Luminal Butyrate Concentrations. J Nutr. 1997;127(11):2217-25.

[210] Pearson JR, Gill CI, Rowland IR. Diet, fecal water, and colon cancer - development of a biomarker. Nutrition Reviews. 2009;67(9):509-26.

[211] Fuchs CS, Giovannucci EL, Colditz GA, Hunter DJ, Stampfer MJ, Rosner B, et al. Dietary Fiber and the Risk of Colorectal Cancer and Adenoma in Women. New England Journal of Medicine. 1999;340(3):169-76.

[212] Aklilu M, Kindler HL, Donehower RC, Mani S, Vokes EE. Phase II study of flavopiridol in patients with advanced colorectal cancer. Annals of Oncology. 2003;14(8):1270-3.

[213] Choi H-Y, Ryu H-K, Park K-M, Lee EG, Lee H, Kim S-W, et al. Direct lactic acid fermentation of Jerusalem artichoke tuber extract using Lactobacillus paracasei without acidic or enzymatic inulin hydrolysis. Bioresource Technology. 2012;114(0):745-7.

[214] Tuohy KM, Kolida S, Lustenberger AMaG, G.R. The prebiotic effects of biscuits containing partially hydrolysed guar gum and fructo-oligosaccharides ? A human volunteer study. British Journal of Nutrition 2001;86 341-8.

[215] Bouhnik Y, Raskine L, Simoneau G, Vicaut E, Neut C, Flourié B, et al. The capacity of nondigestible carbohydrates to stimulate fecal bifidobacteria in healthy humans: A double-blind, randomized, placebo-controlled, parallelgroup, dose-response relation study. The American Journal of Clinical Nutrition. 2004;80(6):1658-64.

[216] Kleessen B, Schwarz S, Boehm A, Fuhrmann H, Richter A, Henle T, et al. Jerusalem artichoke and chicory inulin in bakery products affect faecal microbiota of healthy volunteers. British Journal of Nutrition. 2007;98(03):540-9. 
[217] Bouhnik Y, Attar A, Joly FA, Riottot M, Dyard F, Flourie B. Lactulose ingestion increases faecal bifidobacterial counts: A randomised double-blind study in healthy humans. Eur $\mathbf{J}$ Clin Nutr. 2004;58(3):462-6.

[218] Kleessen B, Hartmann L, Blaut M. Oligofructose and longchain inulin: Influence on the gut microbial ecology of rats associated with a human faecal flora. British Journal of Nutrition. 2001;86:291-300.

[219] Rycroft CE, Jones MR, Gibson GR, Rastall RA. A comparative in vitro evaluation of the fermentation properties of prebiotic oligosaccharides. Journal of Applied Microbiology. 2001;91(5):878-87.

[220] Vardakou M, Nueno Palop C, Gasson M, Narbad A, Christakopoulos P. In vitro three-stage continuous fermentation of wheat arabinoxylan fractions and induction of hydrolase activity by the gut microflora. International Journal of Biological Macromolecules. 2007;41(5):584-9.

[221] Connolly ML, Lovegrove JA, Tuohy KM. In vitro evaluation of the microbiota modulation abilities of different sized whole oat grain flakes. Anaerobe. 2010;16(5):483-8.

[222] Kedia G, Vázquez J, Charalampopoulos D, Pandiella S. In Vitro Fermentation of Oat Bran Obtained by Debranning with a Mixed Culture of Human Fecal Bacteria. Current Microbiology. 2009;58(4):338-42.

[223] Hughes SA, Shewry PR, Gibson GR, McCleary BV, Rastall RA. In vitro fermentation of oat and barley derived $\beta$-glucans by human faecal microbiota. FEMS Microbiology Ecology. 2008;64(3):482-93.

[224] Cani PD, Lecourt E, Dewulf EM, Sohet FM, Pachikian BD, Naslain D, et al. Gut microbiota fermentation of prebiotics increases satietogenic and incretin gut peptide production with consequences for appetite sensation and glucose response after a meal. The American Journal of Clinical Nutrition. 2009;90(5):1236-43.

[225] Beyer-Sehlmeyer G, Glei M, Hartmann E, Hughes R, Persin C, Böhm V, et al. Butyrate is only one of several growth inhibitors produced during gut flora-mediated fermentation of dietary fibre sources. British Journal of Nutrition. 2003;90(06):1057-70.

[226] Pan X, Chen F, WU T, Tang H, Zhao Z. Prebiotic oligosaccharides change the concentrations of short-chain fatty acids and the microbial population of mouse bowel. Journal of Zhejiang University - Science B 2009;10:258-63.

[227] Medina V, Edmonds B, Young GP, James R, Appleton $\mathrm{S}$, Zalewski PD. Induction of Caspase-3 Protease Activity and Apoptosis by Butyrate and Trichostatin A (Inhibitors of Histone Deacetylase): Dependence on Protein Synthesis and Synergy with a Mitochondrial/Cytochrome c-dependent Pathway Cancer Res 1997;57:3697-707.

[228] Wächtershäuser A, Stein J. Rationale for the luminal provision of butyrate in intestinal diseases. European Journal of Nutrition. 2000;39(4):164-71.

[229] Klampfer L, Huang J, Sasazuki T, Shirasawa S, Augenlicht L. Inhibition of Interferon $\gamma$ Signaling by the Short Chain Fatty Acid Butyrate11Montefiore Medical Center New Research Initiative Award to L.K. and the American Cancer Society Institutional Research Grant to L.K. (ACS IRG \#98-27401), UO1 CA88104 (to L.A.), and P30-13330 from NCI. Molecular Cancer Research. 2003;1(11):855-62.
[230] Mariadason JM, Velcich A, Wilson AJ, Augenlicht LH, Gibson PR. Resistance to Butyrate-Induced Cell Differentiation and Apoptosis During Spontaneous Caco-2 Cell Differentiation Gastroenterology. 2001;120:889-99.

[231] Roy M-J, Dionne S, Marx G, Qureshi I, Sarma D, Levy E, et al. In vitro studies on the inhibition of colon cancer by butyrate and carnitine. Nutrition. 2009;25(11-12):1193-201.

[232] McCartney AL, Wenzhi W, Tannock GW. Molecular analysis of the composition of the bifidobacterial and lactobacillus microflora of humans. Applied and Environmental Microbiology. 1996;62(12):4608-13.

[233] Bäckhed F, Ley RE, Sonnenburg JL, Peterson DA, Gordon JI. Host-Bacterial Mutualism in the Human Intestine. Science. 2005;307(5717):1915-20.

[234] Blaut M, Collins MD, Welling GW, Doré J, van Loo J, de Vos W. Molecular biological methods for studying the gut microbiota: The EU human gut flora project. British Journal of Nutrition. 2002;87(SupplementS2):S203-S11.

[235] Key TJ, Appleby PN, Spencer EA, Travis RC, Roddam AW, Allen NE. Cancer incidence in vegetarians: Results from the European Prospective Investigation into Cancer and Nutrition (EPIC-Oxford). The American Journal of Clinical Nutrition. 2009;89(5):1620S-6S.

[236] Nawirska A, Kwaśniewska M. Dietary fibre fractions from fruit and vegetable processing waste. Food Chemistry. 2005;91(2):221-5.

[237] Eid NMS, Al-Awadi B, Vauzour D, Oruna-Concha MJ, Spencer JPE. Effect of Cultivar Type and Ripening on the Polyphenol Content of Date Palm Fruit. Journal of Agricultural and Food Chemistry. 2013;61(10):2453-60.

[238] Chong MF, George TW, Alimbetov D, Jin Y, Weech M, Macready AL, et al. Impact of the quantity and flavonoid content of fruits and vegetables on markers of intake in adults with an increased risk of cardiovascular disease: The FLAVURS trial. Eur J Nutr. 2012.

[239] Rincón A.M., Vásquez A.M., F.C. P. Chemical composition and bioactive compounds of flour of orange (Citrus sinensis), tangerine (Citrus reticulata) and grapefruit (Citrus paradisi) peels cultivated in Venezuela. Arch Latinoam Nutr. 2005;55(3):305-10.

[240] Al-Farsi M, Alasalvar C, Morris A, Baron M, Shahidi F. Compositional and Sensory Characteristics of Three Native Sun-Dried Date (Phoenix dactylifera L.) Varieties Grown in Oman. Journal of Agricultural and Food Chemistry. 2005b;53(19):7586-91.

[241] Lee HC, Jenner AM, Low CS, Lee YK. Effect of tea phenolics and their aromatic fecal bacterial metabolites on intestinal microbiota. Research in Microbiology. 2006;157(9): 876-84.

[242] Ferguson LR, Schlothauer RC. The potential role of nutritional genomics tools in validating high health foods for cancer control: Broccoli as example. Molecular Nutrition \& Food Research. 2012;56(1):126-46.

[243] Singh PN, Fraser GE. Dietary Risk Factors for Colon Cancer in a Low-risk Population. American Journal of Epidemiology. 1998;148(8):761-74.

[244] Nomura AM, Wilkens LR, Murphy SP, Hankin JH, Henderson BE, Pike MC, et al. Association of vegetable, fruit, and grain intakes with colorectal cancer: The Multiethnic 
Cohort Study. The American Journal of Clinical Nutrition. 2008;88(3):730-7.

[245] Sanjoaquin MA, Appleby PN, Thorogood M, Mann JI, Key TJ. Nutrition, lifestyle and colorectal cancer incidence: A prospective investigation of 10998 vegetarians and non-vegetarians in the United Kingdom. Br J Cancer. 2004;90(1):118-21.

[246] Koushik A, Hunter DJ, Spiegelman D, Beeson WL, van den Brandt PA, Buring JE, et al. Fruits, Vegetables, and Colon Cancer Risk in a Pooled Analysis of 14 Cohort Studies. Journal of the National Cancer Institute. 2007;99(19):1471-83.

[247] Lin J, Zhang SM, Wu K, Willett WC, Fuchs CS, Giovannucci E. Flavonoid Intake and Colorectal Cancer Risk in Men and Women. American Journal of Epidemiology. 2006;164(7):644-51.

[248] Hirvonen T, Virtamo J, Korhonen P, Albanes D, Pietinen P. Flavonol and flavone intake and the risk of cancer in male smokers (Finland). Cancer Causes \& Control. 2001;12(9):797-802.

[249] Cruz-Correa M, Shoskes DA, Sanchez P, Zhao R, Hylind LM, Wexner SD, et al. Combination Treatment With Curcumin and Quercetin of Adenomas in Familial Adenomatous Polyposis. Clinical Gastroenterology and Hepatology. 2006;4(8):1035-8.

[250] Akhter M, Iwasaki M, Yamaji T, Sasazuki S, Tsugane S. Dietary isoflavone and the risk of colorectal adenoma: A case-control study in Japan. Br J Cancer. 2009;100(11): $1812-6$.

[251] Seow A, Yuan J-M, Sun C-L, Van Den Berg D, Lee H-P, Yu MC. Dietary isothiocyanates, glutathione S-transferase polymorphisms and colorectal cancer risk in the Singapore Chinese Health Study. Carcinogenesis. 2002;23(12):205561.

[252] Graham S, Dayal H, Swanson M, Mittelman A, Wilkinson G. Diet in the Epidemiology of Cancer of the Colon and Rectum. J Natl Cancer Inst. 1978;61:709-14.
[253] Murphy N, Norat T, Ferrari P, Jenab M, Bueno-de-Mesquita B, Skeie G, et al. Dietary Fibre Intake and Risks of Cancers of the Colon and Rectum in the European Prospective Investigation into Cancer and Nutrition (EPIC). PLoS One. 2012;7(6):e39361.

[254] Carvalho-Wells AL, Helmolz K, Nodet C, Molzer C, Leonard $\mathrm{C}$, McKevith B, et al. Determination of the in vivo prebiotic potential of a maize-based whole grain breakfast cereal: A human feeding study. British Journal of Nutrition. 2010;104(09):1353-6.

[255] Hansen L, Skeie G, Landberg R, Lund E, Palmqvist R, Johansson I, et al. Intake of dietary fiber, especially from cereal foods, is associated with lower incidence of colon cancer in the HELGA cohort. International Journal of Cancer. 2012;131(2):469-78.

[256] Tuohy KM, Ziemer CJ, Klinder A, Knöbel Y, Pool-Zobel BL, Gibson GR. A Human Volunteer Study to Determine the Prebiotic Effects of Lactulose Powder on Human Colonic Microbiota. Microbial Ecology in Health and Disease. 2002;14(3):165-73.

[257] Ramnani P, Gaudier E, Bingham M, Bruggen P, Van Tuohy K, Gibson G. Prebiotic effect of fruit and vegetable shots containing Jerusalem artichoke inulin: A human intervention study. Br J Nutr. 2010;104:233-40.

[258] Damen B, Cloetens L, Broekaert W, Francois I, Lescroart $\mathrm{O}$, Trogh I, et al. Consumption of breads containing in situ-produced arabinoxylan oligosaccharides alters gastrointestinal effects in healthy volunteers. J Nutr. 2012;142:470-7.

[259] Walton G, Lu C, Trogh I, Arnaut F, Gibson G. A randomised, double-blind, placebo controlled cross-over study to determine the gastrointestinal effects of consumption of arabinoxylan-oligosaccharides enriched bread in healthy volunteers. Nutrition Journal. 2012;11(1):36. 